\title{
Volatile constituents of exotic fruits from Brazil
}

\author{
Juliano Lemos Bicas a,*, Gustavo Molina ${ }^{\text {b }}$, Ana Paula Dionísio ${ }^{c}$, Francisco Fábio Cavalcante Barros ${ }^{\text {b }}$, \\ Roger Wagner ${ }^{\mathrm{d}}$, Mário Roberto Maróstica Jr. e , Gláucia Maria Pastore ${ }^{\mathrm{b}}$ \\ a Campus Alto Paraopeba, University of São João Del-Rei, Cx. Postal 131, Ouro Branco - MG, 36420-000, Brazil \\ ${ }^{\mathrm{b}}$ Department of Food Science, University of Campinas, CX. Postal 6121, Campinas - SP, 13083-862, Brazil \\ c Embrapa Agroindústria Tropical - CNPAT, Rua Doutora Sara Mesquita, 2270, Bairro Pici. Fortaleza - CE, 60511-110, Brazil \\ d Department of Food Science and Technology, University of Santa Maria, Av. Roraima, Prédio 42, sala 3210, Santa Maria - RS, 97105-900, Brazil \\ e Department of Food and Nutrition, University of Campinas, Cx. Postal 6121, Campinas - SP, 13083-862, Brazil
}

\section{A R T I C L E I N F O}

\section{Article history:}

Received 4 November 2010

Accepted 4 January 2011

\section{Keywords:}

Aroma

Flavor

Tropical fruit

Volatile compounds

\begin{abstract}
A B S T R A C T
Flavor is one of the main attributes of foods and is given by a combination of volatile molecules present in the matrix. This paper reviews the general characteristics and uses and focuses on the volatile composition of selected Brazilian exotic fruits: Brazilian cherry (Eugenia uniflora), acerola (Malpighia glabra L., Malpighia punicifolia L., Malpighia emarginata DC.), jackfruit (Artocarpus heterophyllus), starfruit (Averrhoa carambola) and fruits from the genera Annona (cherimoya, soursop, sugar apple etc.) and fruits from the genera Spondias (S. purpurea, S. mombin and S. tuberosa). This is information important for flavor industry, which use different aroma compounds for the formulation of fragrances and flavorings to be used in foods, cosmetics and perfumes.
\end{abstract}

(c) 2011 Elsevier Ltd. All rights reserved.

\section{Introduction}

The composition of the volatile fraction of foods is essential for the characterization and the identity of these materials. The flavor of a certain product, which is one of the main attributes for sensory analysis and consumer's acceptance, is given by the combination of (usually) many volatile molecules.

In their original matrix, natural volatile molecules usually act as chemical signals that, whether, attract pollinators, detect enemies, and find members of the opposite sex (pheromones) besides other properties. In fruits and vegetables, the volatiles representing their characteristic flavor are generally esters, aldehydes, alcohols, terpenes or their derivatives. Sometimes, one substance alone is able to reflect the approximate flavor of a product and, in this case, it is called "impact compound". But, in some circumstances, it is the combination of substances that, together, interacts with the receptors from the nasal mucosa and is interpreted by the brain to create a sensory impression typical for each product. In all cases, aroma compounds are extremely important for industry and are used for the elaboration of different products, from foods, beverages and cosmetics to perfumes.

The flavor compositions of different tropical fruits have already been described for guava, banana, mango, melon, papaya, passion fruit, pineapple, cupuaçu and bacuri (Maróstica \& Pastore, 2007) and

\footnotetext{
* Corresponding author. Tel./fax: + 553137413280 .

E-mail address: jlbicas@gmail.com (J.L. Bicas).
}

also for other Brazilian fruits (Augusto, Valente, Tada, \& Rivellino, 2000; Franco \& Shibamoto, 2000). In this paper, the volatile constituents of other exotic fruits - Brazilian cherry, acerola, jackfruit, starfruit, and fruits from the genera Annonas and Spondias - are reviewed. These fruits present an increasing economic importance in tropical regions, especially in the field of eccentric juices' market. However, only few studies report their properties and characterize their volatile fraction. This paper aims to compile the information available about the volatile compounds present in these fruits in order to diffuse the importance of such fruits and to promote researches in this field. Different analytical methods for the volatile fraction analysis are also presented.

\section{Brazilian cherry (Eugenia uniflora L.)}

Brazilian cherry (E. uniflora L.) - also known as Brazilian cherry, Surinam cherry, cayenne cherry, nangapiri or pitanga - belongs to the Myrtaceae family. This plant, which can grow as bush or tree reaching up to $10 \mathrm{~m}$ high, is native from Brazil and is well adapted to tropical and subtropical regions of South America. Due to its huge adaptability to different soil and climate conditions, this plant has spread to other locations, e.g. California, Florida, Caribbean Islands, China and South of France (Silva, 2006; Vizzotto, 2008). It is commonly found between the Northern part of Brazil and the state of São Paulo, where it is frequently cultivated in gardens. The major production region, in a commercial scale, is the state of Pernambuco (Brazil), with an annual production of approximately 1700 tons of fruits (Silva, 2006). 
This cherry looks like a small pumpkin: it is an orange-to-dark red (reaching dark purple) berry, approximately $3 \mathrm{~cm}$ in diameter, with eight longitudinal grooves. The fruit's pulp, corresponding to $\sim 77 \%$ of the whole fruit, is the main form of commercialization. It has been exported mainly to the European Market (Silva, 2006). Pitanga's frozen pulp, when compared to other fruits, is characterized by a low lipid and caloric content and by high amounts of polyphenols and carotenoids (Spada, Souza, Bertolini, Henriques, \& Salvador, 2008) and other antioxidant compounds (Lima, Melo, \& Lima, 2002). Their seeds (one or two per fruit) are also known as source of bioactive compounds, and as antibacterial agents (Oliveira et al., 2008), besides its high content of phenolic compounds and dietary fibers (Bagetti, Facco, Rodrigues, Vizzotto, \& Emanuelli, 2009). The leaves from E. uniflora are also source of functional compounds. Traditionally used in folk medicine as antipyretic, stomachic, hypoglycemic and to lower blood pressure (Auricchio \& Bacchi, 2003; Melo, Corrêa, Amorim, Miranda, \& Rezende, 2007), some pharmacological effects of leaf extracts have been evaluated (Amorim, Lima, Hovell, Miranda, \& Rezende, 2009; Arai et al., 1999; Consolini, Baldini, \& Amat, 1999; Consolini \& Sarubbio, 2002; Matsumura et al., 2000; Schapoval, Silveira, Miranda, Alice, \& Henriques, 1994). Antibacterial and cytotoxic effects of essential oil of $E$. uniflora have also been reported (Ogunwande et al., 2005).

In Brazil, pitanga is consumed mainly in natura during the harvest period, but the food industry also processes the fruits for the preparation of frozen pulps and juices, besides jellies, candies, ice creams, wine and liquor (Franzão \& Melo, 2010; Oliveira, Kamimura, \& Rabi, 2009). Moreover, the Brazilian cosmetic industry has adopted the essential oils from this plant for the formulation of shampoos, hair conditioners, soaps, body oils and perfumes mainly due to their astringent properties and agreeable smell (Amorim et al., 2009). In fact, besides its high amount of antioxidants (Filho et al., 2008), the exotic and an agreeable unique flavor of pitanga fruits is the main appealing attribute to attract the preference of consumers.

Great part of the published papers dealing with volatile composition of E. uniflora are focused on leaves (Amorim et al., 2009), but the volatile compounds found in fruits have also been subject of some studies (Table 1). It was determined by a trapping-elution procedure that monoterpenes were the largest class of volatiles in the fruits, comprising $3 / 4$ of the 29 volatile compounds identified by gas chromatography-mass spectrometry (GC/MS). The isomeric hydrocarbon ocimene (Fig. 1) was the major substance, followed by ß-pinene (Oliveira, Lopes, Cabral, \& Eberlin, 2006). Similar compounds, although not in the same proportion, were found for fruits' essential oil obtained from hydrodistillation: $(E)$ - $\beta$-ocimene $(7.4 \%)$, $\alpha$-selinene (7.2\%), $\beta$-selinene (5.2\%), germacrene B (7.2\%) and hexadecanoic acid (11.7\%) were the main compounds detected (Marin et al., 2008). In this study, sesquiterpenes showed to be the most abundant compounds. This profile was also seen in other papers.

Using a different recovery technique (simultaneous steam distillation/solvent extraction), Pino, Bello, Urquiola, Aguero, and Marbot (2003) found different mono and sesquiterpenes, being curzerene (synonym for furanoelemene) and bergapten the major constituents of the volatile fraction. When comparing the volatile compounds from leaves and fruits, Ogunwande et al. (2005) reported that for both cases sesquiterpenes (especially their oxygenated derivatives) were the most abundant class of substances, while monoterpene hydrocarbons were found in minor quantities. The major volatile components from fruits were germacrone (27.5\%), selina-1,3,7(11)-trien-8one (19.2\%), curzerene (11.3\%) and oxidoselina-1,3,7(11)-trien-8-one (11.0\%) (Fig. 1). Selina-1,3,7(11)-trien-8-one was found in many fruits and leaf essential oils and is considered the major component of the essential oil from leaves of E. uniflora (Kanazawa, Patin, \& Greene, 2000; Oliveira et al., 2006).

As may be noticed, many changes in composition may be found. Even fruits from the same specie cultivated at the same region present huge variations (Moreno et al., 2007). This may be explained by: (i) the effect of extrinsic conditions, (ii) the effect of interspecific and infraspecific differences, (iii) the effect of ontogeny, (iv) the effect of processing parameters and ( $v$ ) the effect of adulteration (Shu \& Lawrence, 1997). Some main specific examples are the influence of the genotype and the environmental and growing conditions and the extraction procedure. This could divide the essential oils from E. uniflora into at least three different chemotypes (Ogunwande et al., 2005).

Since many odor active compounds may occur at very low concentrations, there is an important distinction between volatile analysis and aroma analysis. Therefore, in a recent study, supercritical $\mathrm{CO}_{2}$ extracts of pitanga fruits obtained from different conditions were subjected to sensory analysis and the results were interpreted using Factorial Discriminant Analysis (FDA) and Principal Component Analysis (PCA). The authors found that flavor intensity and the total amount of compounds in the extract were negatively correlated (the flavor was weak in extracts containing high amounts of compounds

Table 1

The main compounds found in essential oil of Brazilian cherry (E. uniflora) using different analytical methods. Some of their structures are found in Figs. 1 and 5.

\begin{tabular}{|c|c|c|c|}
\hline Analytical method & Compound & Flavor & Ref. $^{a}$ \\
\hline Trapping-elution followed by GC/MS & $\begin{array}{l}\text { cis- and trans- } \beta \text {-ocimene } \\
\beta \text {-pinene }\end{array}$ & $\begin{array}{l}\text { Citrus, green, lime } \\
\text { Pine, turpentine, resin }\end{array}$ & 1) \\
\hline Hydrodistillation followed by GC and GC/MS & $\begin{array}{l}\text { trans- } \beta \text {-ocimene } \\
\alpha \text { - and } \beta \text {-selinene } \\
\text { germacrene } B \\
\text { hexadecanoic acid }\end{array}$ & $\begin{array}{l}\text { Citrus, green, lime } \\
\text { Herbal, amber } \\
\text { Wood, earth, spice } \\
\text { Wax, fat }\end{array}$ & 2) \\
\hline Hydrodistillation followed by GC/MS & $\begin{array}{l}\text { germacrone } \\
\text { selina-1,3,7(11)-trien-8-one } \\
\text { curzerene (furanoelemene) } \\
\text { oxidoselina-1,3,7(11)-trien-8-one }\end{array}$ & $\begin{array}{l}\text { Wood, perfume-like } \\
\text { Green, wood, geranium }\end{array}$ & 3) \\
\hline $\begin{array}{l}\text { Simultaneous steam distillation/solvent } \\
\text { extraction and GC/MS }\end{array}$ & $\begin{array}{l}\text { curzerene (furanoelemene) } \\
\text { bergapten }\end{array}$ & Green, wood, geranium & 4) \\
\hline $\begin{array}{l}\text { Supercritical } \mathrm{CO}_{2} \text { extraction, identification by GC/MS } \\
\text { and sensory analysis assisted by PCA and FDA }\end{array}$ & $\begin{array}{l}\beta \text {-damascenone } \\
\text { 5,6,7,7a-tetrahydro-4-4-7a-trimethyl-2(4H)-benzofuranone } \\
\text { germacrene B } \\
\text { spathulenol } \\
\text { selina-1,3,7(11)-trien-8-one } \\
\text { 10-(1-methylethenyl)-(E, E)-3,7-cyclodecadien-1-one } \\
\text { farnesyl acetone } \\
\text { 2-ethyl-2-methyl-tridecanol }\end{array}$ & $\begin{array}{l}\text { Fruity, floral, sweet } \\
\text { musk } \\
\text { Wood, earth, spice } \\
\text { Wood, earth, herbal, fruity } \\
\text { Fruity, floral, creamy }\end{array}$ & 5) \\
\hline
\end{tabular}

\footnotetext{
a References: 1) Oliveira et al. (2006); 2) Marin et al. (2008); 3) Ogunwande et al. (2005); 4) Pino, Bello, et al. (2003); 5) Malaman et al. (2010).
} 
<smiles>C=C/C(C)=C\CC=C(C)C</smiles>

cis-ocimene<smiles>C=C/C(C)=C/CC=C(C)C</smiles>

trans-ocimene<smiles>CC1=CC=C[C@]2(C)CC(=O)C(=C(C)C)CC12</smiles>

selina-1,3,7(11)-trien-8-one<smiles>CC1=CCC(=C(C)C)C(=O)CC(C)=CC1</smiles>

germacrone<smiles>C=C[C@]1(C)Cc2occ(C)c2CC1C(=C)C</smiles>

curzerene<smiles>C/C=C/C(=O)C1=C(C)C=CCC1(C)C</smiles>

$\beta$-damascenone<smiles>C=C1C=C2[C@@H](CCCC2(C)C)O1</smiles>

5,6,7,7a-tretraydro-4-4-7a-trimethyl-2(4H)benzofuranone<smiles></smiles>

spathulenol

Fig. 1. Some of the main compounds present in the volatile fraction of Eugenia uniflora.

and vice-versa), leading to the conclusion that the characteristic aroma compounds were easily extracted and that the increase in extraction yield did not contribute to increase flavor. The main compounds contributing to pitanga's characteristic flavor were sesquiterpenes and ketones present in the essential oil, specifically $\beta$-damascenone, 5,6,7,7a-tetrahydro-4-4-7a-trimethyl-2(4H)-benzofuranone, germacrene $B$, spathulenol, selina-1,3,7(11)-trien-8-one, 10-(1-methylethenyl)-(E, E)-3,7-cyclodecadien-1-one, farnesyl acetone and 2-ethyl-2-methyl-tridecanol (Fig. 1) (Malaman, Moraes, West, Ferreira, \& Oliveira, 2010). Another group applied Gas Chromatography-Olfactometry (GC-O) technique to determine the main aroma compounds in the essential oil from leaves of $E$. uniflora. The results revealed that, considering the Flavor Dilution Factors (FD), the mixture of furanodiene (along with furanoelemene, FD 1024), $\beta$-elemene (FD 256) and (E,E)-germacrone (FD 256) resulted in a flavor composition with a typical essence of pitanga (Melo et al., 2007). These data seem to corroborate the results obtained by Rücker, Silva, Bauer, and Schikarski (1977), who found that the main compounds identified in the essential oil of Stenocalyx michelii (synonym for E. uniflora) fruits were the sesquiterpenes furanoelemene (curzerene), germacrene- $B, \gamma$-elemene and selina-4 (14), 7 (11)-diene.

\section{Acerola (Malpighia sp.)}

Acerola fruit (Malpighia glabra L., Malpighia punicifolia L., Malpighia emarginata DC.) - also known as Barbados cherry or West-Indian cherry - is useful in the human diet (Assis, Fernandes, Martins, \& Oliveira, 2008) and can be considered as a potential alternative source of income in agricultural businesses (Netto et al., 1996). Member of the Malpighiaceae family (Johnson, 2003), this plant originated in Central America but due to its good adaptation to soil and climate it has been propagated to North America, South America, Amazonian region and more recently introduced in subtropical areas throughout the world, including Asia and India (Assis et al., 2008, Vendramini \& Trugo, 2000). The genus Malpighia comprises 30 species of shrubs and small trees, which provides flowers and fruits at different stages and is observed to have long fruiting periods during the year (Speirs \& Brady, 1991). The fruit is small and red-colored at mature stage, quite similar to a cherry, and its pulp is very juicy, cooling and possesses a fruity and sweet flavor (Gomez, Reynes, Dornier, \& Hebert, 1999; Johnson, 2003). Despite being very appreciated for its flavor and color, it is also nutritionally important due to its high vitamin C content (1000$4500 \mathrm{mg}$ of vitamin C per $100 \mathrm{~g}$ of fruit) (Johnson, 2003; Leung \& Foster, 1996; Pino \& Marbot, 2001).

Nowadays, acerola can be considered as a tropical fruit of great economic and nutritional potentials, considering that it can be used to prepare different products such as ice cream, gelatin, juice, soft drinks, nectar, jelly, gum, fruit conserve, nutraceutics, yogurts and sodas. Currently, Brazil is the greatest world producer of acerola and competes mainly in the market sector of consumers that prefer natural products (Mezadri, Fernández-Pachón, Villaño, García-Parrilla, \& Troncoso, 2006), because the vitamin C produced by this fruit is better absorbed than synthetic ascorbic acid by the human organism (Araújo \& Minami, 1994).

There are many important reactions for the characteristics of the mature fruit, its ripening and peculiar flavor, including a series of complex biochemical reactions such as hydrolysis of starch, conversion 
of chloroplasts into chromoplasts with chlorophyll transformation, production of carotenoids, anthocyanins, phenolics and the formation of volatile compounds (Speirs \& Brady, 1991; Vendramini \& Trugo, 2000).

The chemical composition of acerola fruit has been published elsewhere (Gomez et al., 1999; Maciel, Melo, Lima, da Silva, \& da Silva, 1999). It is known that the distribution of aroma components is dependent on the species, environmental conditions, and also on the stage of maturity of the fruit but there is little information about the composition of its volatile flavor constituents (Vendramini \& Trugo, 2000).

One of the first reports dealing with the volatile aroma compounds released from acerola was done in 1993, where the authors identified the presence of 3-methyl-but-2-en-1-ol as the major compound and its esters, that seemed to participate in the fruity aroma of the pulp. Some of these compounds were identified for the first time, and it was also observed that some norisoprenoids were responsible for part of acerola fruity aroma (Schippa, George, \& Fellous, 1993).

Pino and Marbot (2001) detected the presence of different compounds, including monoterpenoids that were not found in other studies. Authors investigated the volatile flavor constituents of the acerola cultivated in Cuba, compounds were isolated by simultaneous steam distillation-solvent and analyzed by GC and GC/MS methods. Among one hundred fifty constituents, the major components identified in the aroma concentrate were found to be furfural, hexadecanoic acid, 3-methyl-3-buten-1-ol and limonene (Fig. 2). It was also discussed that the amounts of esters seemed to contribute to the unique flavor of the acerola fruit.

Another group applied GC/MS to evaluate the effect of three different stages of maturity on the chemical composition and volatile components of acerola ( $M$. punicifolia L.). The development of the aroma profile was evidenced by the increase in the number of identified compounds in the following order: 14 in the immature (green) fruit, 23 in the intermediate (yellow), such as methyl hexanoate and 3-octen-1-ol, while in the mature and red fruits 31 compounds were found, such as acetyl-methyl-carbinol and ethyl hexanoate. Authors also observed that when green odor prevailed during the first stage of maturity, ester concentrations were low and increase during maturation (Vendramini \& Trugo, 2000). This increase could be explained by its formation from reactions of alcohols and organic acids catalysed by alcohol acyltransferases which are highly active during fruit maturation and appear to have an important role in ester biosynthesis (Olias, Sanz, Rios, \& Perez, 1995).

In another paper, authors identified free and glycosidically-bound flavor compounds of acerola fruit by GC and GC/MS. It was observed that among 46 compounds identified in the volatile fraction the majority were alcohols, such as 3-methyl-but-3-1-ol, 3-methyl-butan-1-ol and 2-methyl-butan-1-ol. There were also 42 aglycones identified for the first time in this fruit and they observed that alcohols and norisoprenoids were predominant. According to the authors, the hydrolysis of these aglycones could increase the fruity aroma of acerola. Finally, using GC/EIMS based on its TFA derivatives four glucosides and one rutinoside were characterized in this fruit (Boulanger \& Crouzet, 2001). Table 2 includes some important compounds that contribute to the fruity and fresh aroma of acerola.

Over the years, several compounds that play important roles on the aromatic profile of acerola have been characterized. In general, scientific papers discuss the importance of some aromatic compounds, alcohols and esters that can participate in the fresh and fruity aroma of acerola (Boulanger \& Crouzet, 2001; Pino \& Marbot, 2001).

\section{Jackfruit (Artocarpus heterophyllus L.)}

Jackfruit (A. heterophyllus L.) is an exotic fruit that belongs to the Moraceae family. It originated from India and is widely grown in several countries of tropical climates, like Brazil, Bangladesh, Nigeria, Sri Lanka, Malaysia, Indonesia and Philippines (Ajayi, 2008; Narasimham, 1990). The tree is high up to $20 \mathrm{~m}$ and their fruits usually reach $10-25 \mathrm{~kg}$ per unit in weight at maturity (Rahman, Huq, Mian, \& Chesson, 1995). The yellowish bulbs constituting the perianth portion of the fruit are fleshy, fibrous, and rich in sugars. In Brazil, according to the consistency and size of the fruits, the species are known as "jaca-dura" (hard jackfruit) and "jaca-mole" (soft jackfruit). The pulp of the former is harder in comparison with the latter that often is also called butter-jackfruit. On the other hand, the aroma of both fruits is very distinguishable. Hard jackfruit is bigger than the soft, while the latter is often more sweet and aromatic (Cavalcante, 1991; Maia, Andrade, \& Zoghbi, 2004). This fruit is consumed both as a vegetable in the unripe stage and also as a fruit when ripe (Ong et al., 2006). Additionally, some products also can be developed

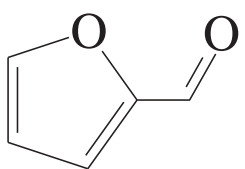

furfural

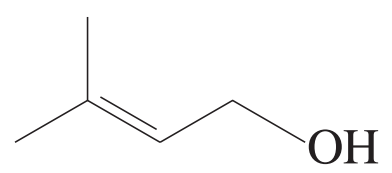

3-methyl-but-2-en-1-ol

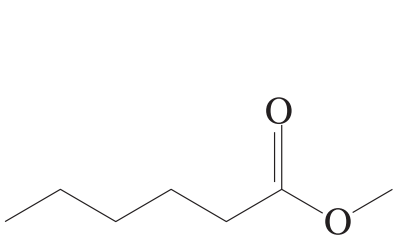

methyl hexanoate 3-octen-1-ol<smiles>C=CC(O)CCCCC</smiles>

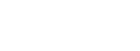

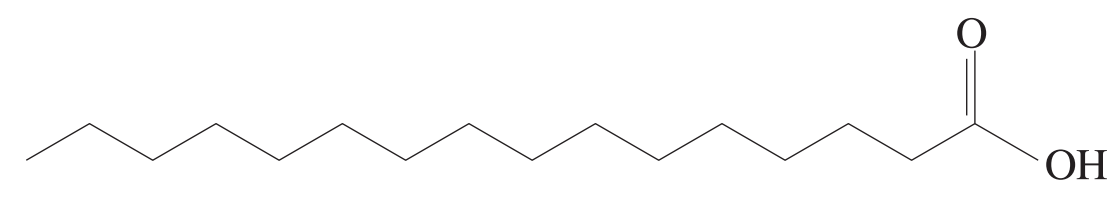

hexadecanoic acid

Fig. 2. Some examples of the compounds present in the volatile fraction of Malgiphia sp., such as esters, alcohols and terpenes. 
Table 2

The main compounds found in Acerola (Malpighia sp.) using different analytical methods. Some of their structures are found in Fig. 2.

\begin{tabular}{|c|c|c|c|}
\hline Analytical method & Compound & Flavor & Ref. $^{\text {a }}$ \\
\hline \multirow{4}{*}{$\begin{array}{l}\text { Simultaneous steam } \\
\text { distillation/solvent } \\
\text { extraction and GC/MS }\end{array}$} & Furfural & Almond & \multirow[t]{4}{*}{ 1) } \\
\hline & 3-methyl-3-buten-1-ol & Fruity notes & \\
\hline & hexadecanoic acid & Wax, fat & \\
\hline & Limonene & Citric & \\
\hline \multirow{6}{*}{$\begin{array}{l}\text { Hydrodistillation } \\
\text { followed by GC } \\
\text { and GC/MS }\end{array}$} & acetyl-methyl-carbinol & $\begin{array}{l}\text { Pleasant } \\
\text { buttery odor }\end{array}$ & \multirow[t]{6}{*}{ 2) } \\
\hline & 2-methyl-propyl-acetate & Fruity, floral & \\
\hline & ethyl hexanoate & $\begin{array}{l}\text { Fruity, such as } \\
\text { banana and } \\
\text { pineapple }\end{array}$ & \\
\hline & isoprenyl butyrate & & \\
\hline & Acetofenone & $\begin{array}{l}\text { Important } \\
\text { compounds to } \\
\text { the mature } \\
\text { and red fruits }\end{array}$ & \\
\hline & E-Z-octenal & & \\
\hline \multirow{4}{*}{$\begin{array}{l}\text { Simultaneous } \\
\text { distillation extraction, } \\
\text { solid phase extraction } \\
\text { and GC/MS }\end{array}$} & Alcohols, such as 3- & Fresh and fruity & \multirow[t]{4}{*}{ 3) } \\
\hline & methyl-but-3-1-ol, & & \\
\hline & $\begin{array}{l}\text { 3-methyl-butan-1-ol } \\
\text { and 2-methyl-butan-1-ol }\end{array}$ & & \\
\hline & Norisoprenoids & Fruity & \\
\hline
\end{tabular}

a References: 1) Pino and Marbot (2001); 2) Vendramini and Trugo (2000): 3) Boulanger and Crouzet (2001).

as a pickle, cooked or as sweet (Cavalcante, 1991), fermented alcoholic (Asquieri, Rabelo, \& Silva, 2008), drum-dried powder (Pua, Hamid, Rusul, \& Rahman, 2007) and dehydrated product (Oliveira, 2009). The fruit can be described as a rich source of carbohydrates, minerals, carboxylic acids, dietary fiber, ascorbic acid, thiamine (Rahman, Nahar, Mian, \& Mosihuzzaman, 1999) and carotenoids (Faria, Rosso, \& Mercadante, 2009).

The aroma of jackfruit is described with strong peculiar fruit notes, which can be altered by different cultivars involved as well as a wide range of preharvest and postharvest conditions (Ong et al., 2008). Only a few studies can be found in literature about volatile compounds of this fruit and their odor importance. It is known that the method involved in a volatile isolation process affects drastically the volatile profile of a food. However, independent of the method applied for volatile compound analyses, esters chemical class has been highlighted in abundance as well as sensory impact in jackfruit, some of them are illustrated in Fig. 3. Other compound classes like alcohols, acids and aldehydes are also reported in volatile composition (Maia et al., 2004; Ong et al., 2006). Table 3 presents the main compounds that possibly contribute to the characteristic aroma of jackfruit extracted by different methods.

Swords, Swords, Bobbio, and Hunter (1978) identified 20 volatile compounds in the steam-distillation extract of jackfruit. The majority of compounds reported were not only the alcohols butanol, isoamyl alcohol, hexanol and octanol but also the esters butyl isovalerate, butyl butanoate, isoamyl isovalerate, butyl acetate and propyl isovalerate. Rasmussen (1983) reported 21 compounds with similar extract composition. Wong, Lim, and Wong (1992) analyzed the steam-distilled volatile constituents from fruits grown in Malaysia by capillary GC and GC/MS, revealing 45 volatile components of which 32 have not been reported previously. The authors

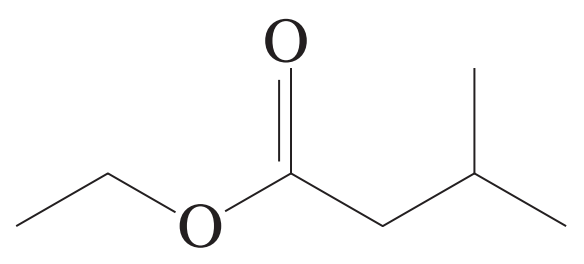

ethyl 3-methylbutanoate

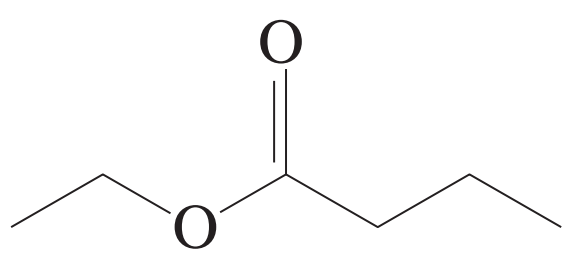

ethyl butanoate

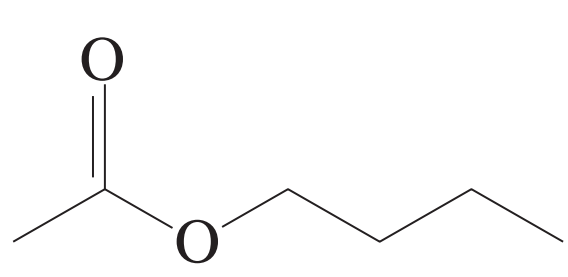

butyl acetate

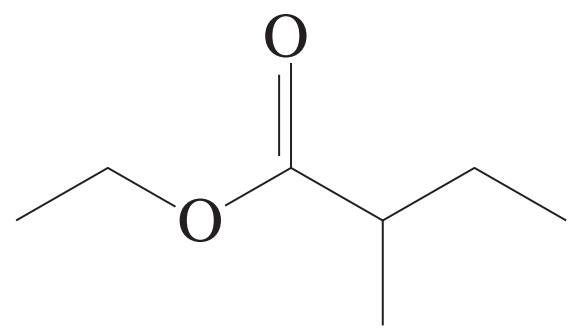

ethyl 2-methylbutanoate

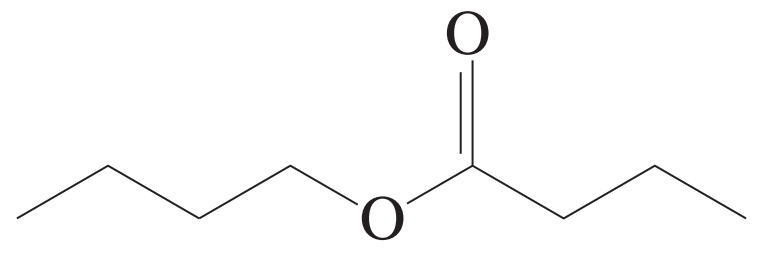

butyl butanoate

Fig. 3. Odor impact compounds present in the volatile fraction of jackfruit (Artocarpus heterophyllus L.). 
Table 3

The main compounds found in jackfruit (Artocarpus heterophyllus L.) using different analytical methods. Some of their structures are found in Fig. 3.

\begin{tabular}{|c|c|c|c|}
\hline Analytical method & Compound & Flavor & Ref. $^{a}$ \\
\hline Simultaneous Distillation-Extraction (SDE) & $\begin{array}{l}\text { isopentyl 3-methylbutanoate } \\
\text { butyl 3-methylbutanoate } \\
\text { butyl acetate } \\
\text { ethyl 3-methylbutanoate } \\
\text { 2-methylbutyl acetate }\end{array}$ & $\begin{array}{l}\text { Fruity, apple } \\
\text { Fruity } \\
\text { Sweet, fruity, banana, pear } \\
\text { Cashew, fruity, sweet fruit } \\
\text { Fermented-fruity, banana }\end{array}$ & 1) \\
\hline Headspace technique followed by GC/MS and GC-O & $\begin{array}{l}\text { ethyl 3-methylbutanoate } \\
\text { ethyl butanoate } \\
\text { butyl butanoate } \\
\text { ethyl 2-methylbutanoate }\end{array}$ & $\begin{array}{l}\text { These compounds were reported as characteristic } \\
\text { fruity notes in Brazilian jackfruit }\end{array}$ & 2) \\
\hline SPME (DVB-CAR-PDMS) followed by GC/TOFMS & $\begin{array}{l}\text { ethyl isovalerate } \\
\text { 3-methylbutyl acetate } \\
\text { propyl isovalerate } \\
\text { isobutyl isovalerate } \\
\text { 2-methylbutanol } \\
\text { butyl isovalerate }\end{array}$ & $\begin{array}{l}\text { Compounds that possibly contribute to fruity notes and } \\
\text { common in different cultivars of Malaysian jackfruits }\end{array}$ & 3) \\
\hline
\end{tabular}

a References: 1) Maia et al. (2004); 2) Fraga (2005); 3) Ong et al. (2008).

pointed out that esters represented a high proportion (31.9\%) of the jackfruit volatiles and are important contributors to the flavor of this fruit.

In Brazil, the volatile compounds from two fruit varieties ("hard" and "soft") growing in the Amazon were studied by Maia et al. (2004). The authors reported isopentyl isovalerate (28.4\%) and butyl isovalerate (25.6\%) as major components identified in the extract concentrate of the "hard" variety obtained by Simultaneous Distillation-Extraction (SDE). While in the extract concentrate of "soft jackfruit" was marked by isopentyl isovalerate (18.3\%), butyl acetate (16.5\%), ethyl isovalerate (14.4\%), butyl isovalerate (12.9\%) and 2-methylbutyl acetate (12.0\%). According with the authors' conclusion, the chemical composition suggests that the two morphological variations of jackfruit are also represented by two different chemotypes belonging to $A$. heterophyllus species.

Fraga (2005) evaluated the odoriferous quality of the different jackfruit extracts, obtained by SDE, LLE (liquid-liquid extraction) and headspace techniques. In this study, the headspace extract possesses major similarity with the fresh fruit aroma. In the headspace jackfruit extracts were identified to have 59 volatile compounds, where the majority was marked by esters content (68\%), followed by alcohols (16\%), acids (8\%) and aldehydes (8\%). The ethylic and butyric esters provided of C4 to C6 linear chain dominated in global composition of jackfruit pulp. The same extract was submitted to GC-O by Aroma Extraction Dilution Analysis (AEDA), the results revealed high FD for the compounds ethyl 3-methylbutanoate $(F D=512)$, ethyl butanoate $(\mathrm{FD}=256)$ and butyl butanoate and ethyl 2-methylbutanoate $(\mathrm{FD}=128)$ characterizing the major odor impacts found in fresh jackfruit pulp. The author found high proportion of isoamylic and amylic alcohols in the chromatogram. However, these alcohols presented poor odor contribution for global aroma of the fruit, being perceived only in the first extract dilution.

Chemical composition and flavor changes during ripening of jackfruit cultivar J3 from Malaysia were studied by Ong et al. (2006). Relevant changes in volatile composition were revealed in three different portions of jackfruit fresh pulp (top, middle and button) during $1,3,5$ and 6 days after harvest. A total of 23 volatile compounds were detected in all experiments. The authors observed an increase of number of compounds in the extracts during the ripening process. In days 5 and 6 after harvest in ripened fruit the compounds butyl acetate and 3-methylbutyl acetate appeared, which contributed to the fruity and floral flavor notes of the fruit. On the other hand, 3-phenylpropanol, palmitic acid, stearic acid and oleic acid were found in large amounts in the day 1 fruit, but a decrease in fatty acids was observed throughout the ripening. Thus, based on data obtained authors suggested that the optimum stage of ripening of jackfruit was at day 5 after harvest.
More recently, Ong et al. (2008) identified from five jackfruit cultivars 37 compounds using a HS-SPME and gas chromatography-time-of-flight mass spectrometry (GC/TOFMS) method, including 20 esters, five alcohols, nine aldehydes, two ketones, and one ether. The main jackfruit volatile compounds reported were: ethyl isovalerate, 3-methylbutyl acetate, 1-butanol, propyl isovalerate, isobutyl isovalerate, 2-methylbutanol, and butyl isovalerate. Additionally, these compounds were consistently present in all the five cultivars and this suggests the compounds contributed to the sweet and fruity note of jackfruit. The data was explored by PCA and efficiently discriminated the five jackfruit cultivars according to their unique flavor compounds. Therefore, quantification of the concentration of volatile compounds present plays an important role in determining the effect of the compounds in the overall flavor of the fruit in each cultivar. Besides, each cultivar had its own unique compound which differentiated them from one to another.

\section{Starfruit (Averrhoa carambola L.)}

Starfruit (also called carambola) (A. carambola L.) is cultivated in many tropical and subtropical countries in the world, like Indonesia, Israel, Malaysia, Florida and countries from Central America (Pino, Marbot, Rosado, \& Bello, 2004). The evergreen starfruit tree's height ranges from 7 to $10 \mathrm{~m}$; the leaves range from 15 to $30 \mathrm{~cm}$ and the flowers are pink to lavender in color (Crane, 1994; MacLeod \& Ames, 1990). Some of its cultivars could be susceptible to wind damage, which results in defoliation, desiccation, stunted growth and fruit damage. The trees protected by wind are more vigorous and productive than wind-exposed trees (Crane, 1994).

The fruit is fleshy, very attractive in appearance, very particular in shape with 5 longitudinal ribs, which provides a star shape in the cross section. Its skin is thin, waxy and yellowish. The flesh is light to dark yellow, without fiber and very juicy. The fruit is low in calories and a good potassium source. Starfruit is mainly commercialized as fresh fruits and does not increase in sugar content after picking. Attempts on the preservation of the post harvesting fruits have already been done (Neves, Bender, Rombaldi, \& Vieites, 2004). They are eaten fresh, in salads or garnishes (Crane, 1994; Wilson, Shaw, Knight, Nagy, \& Klim, 1985), or else, it can be cooked in puddings, tarts and curries. Starfruit's juice and jelly are also much appreciated. The juice is normally served as a cooling beverage. The commercial productions of juices and jellies are small; they are mostly consumed as homemade preparations. Wines can also be done, but it is not available in big commercial scale (Morton, 1987).

Some authors related starfruit flavor as apple-like, apricot-like or grape-like (MacLeod \& Ames, 1990; Wilson et al., 1985). The investigations about its volatile constituents started in the 1980s. Table 4 presents a list of the non-impacting flavor compounds that 
Table 4

List of the non-impacting flavor compounds that contribute to the aroma of starfruit. Some of their structures are found in Figs. 1, 4 and 6.

\begin{tabular}{|c|c|c|c|}
\hline Analytical method & Compound & Flavor & Ref. $^{a}$ \\
\hline $\begin{array}{l}\text { GC-FID after extraction } \\
\text { with dichloromethane }\end{array}$ & $\begin{array}{l}\text { Esters, ketones, } \\
\text { alcohols }\end{array}$ & Fruity & 1) \\
\hline $\begin{array}{l}\text { GC-FID after extraction } \\
\text { with dichloromethane }\end{array}$ & $\begin{array}{l}\text { Ethyl sorbate, } \\
\text { ethyl acetate and } \\
\text { ethyl butyrate, } \\
\alpha \text {-ionone }\end{array}$ & Warm fruity & 1) \\
\hline $\begin{array}{l}\text { GC/FID and GC/MS } \\
\text { analysis after extraction } \\
\text { with a modified Likens } \\
\text { and Nickerson apparatus } \\
\text { using triply distilled } \\
\text { 2-methylbutane }\end{array}$ & $\begin{array}{l}\text { Esters ( } 57 \text { identified } \\
\text { on the extract) and } \\
\text { lactones ( } 9 \text { identified) }\end{array}$ & $\begin{array}{l}\text { Sweet, estery } \\
\text { and fruity }\end{array}$ & 2) \\
\hline $\begin{array}{l}\text { GC/FID and GC/MS analysis } \\
\text { after extraction with a } \\
\text { modified Likens and } \\
\text { Nickerson apparatus using } \\
\text { triply distilled } \\
\text { 2-methylbutane }\end{array}$ & $\begin{array}{l}\alpha \text {-ionone } \\
\beta \text {-damascenone } \\
\alpha \text {-ionol } \\
(Z) \text {-3,4-dehydro- } \\
\alpha \text {-ionone } \\
\text { 4-hydroxy- } \alpha \text {-ionol }\end{array}$ & $\begin{array}{l}\text { Important } \\
\text { contributors } \\
\text { for the fruit } \\
\text { flavor }\end{array}$ & 2) \\
\hline $\begin{array}{l}\text { HRGC-MS, NMR after } \\
\text { simultaneous distillation } \\
\text { extraction, XAD-2 absorption } \\
\text { and preparative GC }\end{array}$ & $\begin{array}{l}\text { norisoprenoid } \\
\text { glycosides }\end{array}$ & $\begin{array}{l}\text { Important } \\
\text { contributor for } \\
\text { the fruit flavor }\end{array}$ & 3) \\
\hline $\begin{array}{l}\text { Gas chromatography after } \\
\text { absorption with Bio-Beads, } \\
\text { recovery with methanol, } \\
\text { concentration and transfer to } \\
\text { SPME fibers }\end{array}$ & $\beta$-ionone & $\begin{array}{l}\text { Important } \\
\text { contributor for } \\
\text { the fruit flavor }\end{array}$ & 4) \\
\hline
\end{tabular}

contribute to the aroma of starfruit. In 1985, Wilson et al. detected 41 volatile components from a dichloromethane extract of starfruit. Seven and a half $\mathrm{kg}$ of starfruit (obtained in Miami, US Subtropical Horticultural Research Station) was deseeded, mixed to an equal amount of deionized water and blended. The filtered cake and aqueous filtrate were extracted with dichloromethane, concentrated and kept at $4{ }^{\circ} \mathrm{C}$. GC/FID and GC/MS analysis revealed several esters, ketones and alcohols. The authors reported methyl anthranilate (Fig. 4), which was described as a distinct grape-like aroma, as the major volatile component. They also related the strong fruity aroma of the extract to the major esters and ketones present on the extract. Ethyl sorbate, ethyl acetate and ethyl butyrate were also found, which, in combination with other esters and ketones like $\alpha$-ionone, could contribute to the warm fruity ethereal flavor.

Later, MacLeod and Ames (1990) reported the identification of volatile components from starfruit. From the 178 compounds identified, 116 were described for the first time as components of starfruit's volatile fraction. The authors highlighted that esters (57 identified on the extract) and lactones (9 identified), together with carotenoid derived compounds like megastigma-4,6,8-trienes and megastigma-5,8-(E) and (Z)-dien-4-one, are significant components of the starfruit aroma. The authors reported the extraction of the volatiles from a Malaysian starfruit with a modified Likens and Nickerson apparatus using triply distilled 2-methylbutane. Four extracts were combined and concentrated. The extract odor was reported as sweet, estery and fruity (peach/apricot/plum-like). GC/ FID and GC/MS analysis were performed. DB5 and BP20 columns were used; most of the compounds were isolated using the first column and fewer of the compounds were analyzed using the second one. The authors reported that the two most abundant classes of compounds identified were 25 aliphatic hydrocarbons and 7 acids, representing 45 and $29 \%$ of the isolate, respectively. However, according to the authors, these compounds do not contribute to the flavor characteristic of the extract. Ester compounds were reported as important impact flavor compounds in carambolas and the authors could identify 57 esters on the extract (9\% of the isolate). Two of the identified esters [di-(2 methylpropyl)phthalate and dioctyl phthalate] were described as artifacts from plasticizers in polymeric packaging films. The authors also commented that carotenoids are important precursors for several volatiles from starfruit. Alphaionone, $\beta$-damascenone, $\alpha$-ionol, (Z)-3,4-dehydro- $\alpha$-ionone and 4 -hydroxy- $\alpha$-ionol were reported as flavor constituents of the starfruit isolate. Furthermore, the authors described (E,E; E,Z; Z,E and $Z, Z$ ) isomers of megastigma-4,6,8-triene, megastigma-5,8(E)dien-4-one and megastigma-5,8(Z)-dien-4-one as important aroma compounds from starfruit (Fig. 4).

Some years after, Winterhalter and Schreier (1995) launched a review about the generation of norisoprenoid volatiles in starfruit. The authors commented the isolation and structural elucidation of several novel C13 and C15-norisoprenoid compounds from starfruit as well as its possible degradative pathways. The authors commented the differences of norisoprenoid derivatives found in different investigations and suggested that the aroma compounds isolation procedures could interfere directly on the norisoprenoid volatile profile. They argue that gentle isolation techniques (like headspace sampling, continuous liquid extraction at low temperature or the combination of high-vacuum distillation with liquid-liquid extraction) could be more appropriate for the determination of the genuine flavor compounds. On the other hand, they assert that simultaneous distillation/extraction technique at atmospheric pressure could expose the sample to high temperatures, resulting in "secondary" volatiles. In order to prove this statement, the authors reported their own experiments relating the differences on the volatile composition due to different extraction conditions. The review also relates the identification of glycosidically bound norisoprenoid flavor precursors in starfruit, where the authors report their own achievements on the extraction and analysis of the glycosidically bound aroma precursors. Furthermore, the authors describe, for the first time, the isolation of

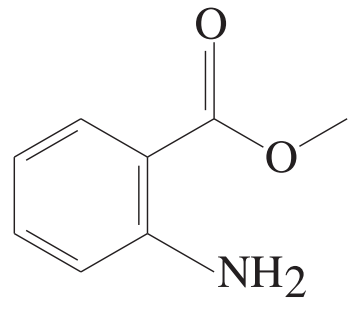

methyl anthranilate

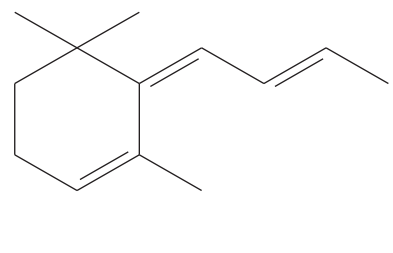

megastigma-4,6,8-triene

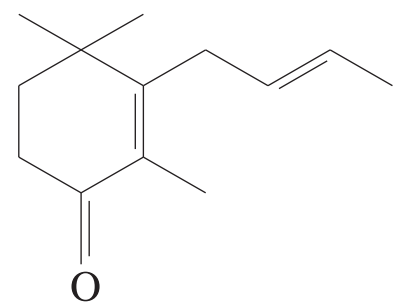

megastigma-5,8-dien-4-on

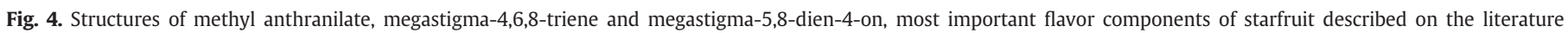
consulted. 
several norisoprenoid glycosides from starfruit. For additional details, we advise the reading of their review.

As stated before, the flavor compounds derived from carotenoids play important roles on the aroma profile of starfruit. In this way, Fleischmann, Watanabe, and Winterhalter (2003) investigated the possible pathways for the conversion of $\beta$-carotene in flavor compounds using enzyme extracts from starfruit. According to the authors, the first description of an enzyme fraction showing carotenoid cleavage activity was isolated from fruit skin of starfruit. An enzymatic protein fraction consisting of 4 proteins ( 12 to $90 \mathrm{kDa}$ ) was obtained. The enzyme converted $\beta$-carotene into $\beta$-ionone as the main product reaction at $45^{\circ} \mathrm{C}$ as optimum temperature. The authors proved that the time course of carotenoid cleavage reaction follows an exponential function typical for first order reactions. They commented that the influence of oxygen is negligible at the conditions studied.

\section{The genus Annona}

The family Annonaceae contains a considerable number of plant species with economic significance because of their edible fruits around the world, namely tropical America, Australia, Africa, India, Malaysia and Mediterranean Europe (Idstein, Herres, \& Schreier, 1984; Shashirekha, Baskaran, Rao, Vijayalakshmi, \& Rajarathnam, 2008). The genus Annona, derived from the Latin word "annual harvest", is the most important source of edible fruits from this family. These species are shrubs or small trees, with height from 5 to $11 \mathrm{~m}$; they are erect or somewhat spreading and possess gray-brown bark, often rough and corrugated (Pino, 2010). Considering that this family have 120 genera (Santos, Andrade, Zoghbil, \& Maia, 1998) and more than 500 species, only the flavor composition of the most common Annona species is summarized in this work, including cherimoya (Annona cherimolia Mill.), soursop (Annona muricata), sugar apple (Annona squamosa), custard apple (Annona reticulata) and pond apple (Annona glabra L.). Table 5 presents a list of some impacting flavor compounds that contribute to the aroma of different species of Annona.

Annona cherimolia Mill. is a subtropical fruit tree that originated from frost-free valleys of the Andes at an altitude of between 700 and $2400 \mathrm{~m}$ (Amoo, Emenike, \& Akpambang, 2008). The common names include cherimoia (Brazil), cabeça-de-negro, anona do Chile (Portugal), chirimorrinon (Venezuela), cherimoya (Colombia, Ecuador, Cuba), anona (Costa Rica), chirimoyo (España, Chile), and others (Pino, 2010). Regardless of its unusual appearance, cherimoya is readily accepted by the Western consumers due to its fine taste and flavor (Pino, 2010). The pulp of this fruit is creamy, very sweet and pleasantly flavored, and it is well known as a dessert fruit and has a lot of applications in ice creams and beverages (Chikhalikar, Sahoo, Singhal, \& Kulkarni, 2000).

Some studies evaluated the volatile compounds of Annona cherimolia. In one of them, the authors identified 208 volatile compounds, including 23 hydrocarbons, 58 esters, 54 alcohols, 47 carbonyls, and 26 volatiles of miscellaneous structures were found. Quantitatively, alcohols such as 1-butanol, 3-methyl-1-butanol, 1-hexanol, and linalool and a series of butanoates and 3-methylbutyl esters comprised the major part of the volatiles (Idstein et al., 1984).

Some authors suggested that the differences observed in the volatile composition of a same fruit could be due to the methodology and/or to different cultivars or geographical regions (Franco \& Janzantti, 2005). Ferreira, Perestrelo, and Câmara (2009) compared the volatile fraction in Funchal, Madeira, Mateus and Perry Vidal cultivars from Annona cherimolia Mill. The analysis of volatile compounds was carried out by headspace solid-phase microextraction (HS-SPME) combined with gas chromatography-quadrupole mass spectrometry detection (GC/qMSD). The study showed that each cherimoya cultivars have 40 common compounds, corresponding to terpenes, esters, alcohols, fatty acids and carbonyl compounds. The major compounds identified in the cherimoya cultivars were methyl butanoate, butyl butanoate, 3-methylbutyl butanoate, 3-methylbutyl 3-methylbutanoate and 5-hydroxymethyl-2-furfural.

Sugar apple (A. squamosa L.) seems to be native to southeastern Mexico, in dry areas and until $1000 \mathrm{~m}$ in altitude, although it grows well in regions of medium humidity. The plant is a small tree which grows wild in many places in the north of South America, Central America, and the Caribbean region. The common names include anona, araticum and fruta-do-conde (Brazil), sweetsop and sugar apple (English language countries), kaneelapell (Suriname), sitaphal

Table 5

The main compounds found in fruits of genus Annona using different analytical methods. Some of their structures are found in Fig. 5.

\begin{tabular}{|c|c|c|c|c|}
\hline Annona specie & Analytical method & Compound & Flavor & Ref. $^{a}$ \\
\hline \multirow[t]{5}{*}{ A. cherimolia } & \multirow{5}{*}{$\begin{array}{l}\text { Headspace solid-phase microextraction (HS-SPME) } \\
\text { combined with gas chromatography-quadrupole } \\
\text { mass spectrometry detection (GC/qMSD). }\end{array}$} & methyl butanoate & Ether, fruit, sweet & \multirow[t]{5}{*}{ 1) } \\
\hline & & butyl butanoate & Fruity, pineapple & \\
\hline & & 3-methylbutyl butanoate & Banana, pineapple, cherry, sweet & \\
\hline & & 3-methylbutyl 3-methylbutanoate & Fruity, sweet, apple, apricot, mango & \\
\hline & & 5-hydroxymethyl 2-furfural & Butter, caramel, musty & \\
\hline \multirow{10}{*}{ A. muricata } & \multirow{8}{*}{$\begin{array}{l}\text { Gas chromatographic/mass spectrometric (GC/FID } \\
\text { and GC/MS) and olfactometric methods }\end{array}$} & methyl 2-hexenoate & Green, fruity, pineapple & \multirow[t]{8}{*}{ 2) } \\
\hline & & methyl 2-octenoate & Fruity, green & \\
\hline & & methyl 2-butenoate & Fruity, green & \\
\hline & & $\alpha$-caryophyllene & Woody & \\
\hline & & 1,8-cineole & Mint, sweet & \\
\hline & & linalool & Flower, lavender & \\
\hline & & $R$-terpineol & Oil, anise, mint & \\
\hline & & $\begin{array}{l}\text { linalyl propionate } \\
\text { calarene }\end{array}$ & Floral & \\
\hline & \multirow{2}{*}{$\begin{array}{l}\text { Gas chromatography and mass spectrometry } \\
\text { detection (GC/MS) }\end{array}$} & methyl hexanoate & Fruity, pineapple & \multirow[t]{2}{*}{ 3) } \\
\hline & & methyl hex-2-enoate & Green, fruity, pineapple & \\
\hline \multirow[t]{4}{*}{ A. squamosa } & \multirow{4}{*}{$\begin{array}{l}\text { Gas chromatography and mass spectrometry } \\
\text { detection (GC/MS) }\end{array}$} & kaur-16-en-18-oic acid & & \multirow[t]{4}{*}{ 4) } \\
\hline & & $\alpha$-pinene & Pine, turpentine & \\
\hline & & sabinene & Pepper, turpentine, wood & \\
\hline & & limonene & Lemon, orange & \\
\hline \multirow[t]{4}{*}{ A. glabra } & \multirow{4}{*}{$\begin{array}{l}\text { Gas chromatography and mass spectrometry } \\
\text { detection (GC/MS) }\end{array}$} & $\alpha$-pinene & Pine, turpentine & \multirow[t]{4}{*}{ 5) } \\
\hline & & limonene & Lemon, orange & \\
\hline & & $\alpha$-phellandrene & Peppery-minty, slightly citrusy & \\
\hline & & $(E)$ - $\beta$-ocimene. & Citrus, green, lime & \\
\hline \multirow[t]{3}{*}{ A. reticulata } & \multirow{3}{*}{$\begin{array}{l}\text { Simultaneous steam distillation-solvent extraction } \\
\text { analyzed by GC/MS }\end{array}$} & $\beta$-pinene & Pine, resin, turpentine & \multirow[t]{3}{*}{ 6) } \\
\hline & & $\alpha$-pinene, & Pine, tupertirn & \\
\hline & & germacrene D & Woody spice & \\
\hline
\end{tabular}

a References: 1) Ferreira et al. (2009), 2) Jirovetz et al. (1998), 3) MacLeod and Pieris (1981), 4) Andrade et al. (2001), 5) Santos et al. (1998), 6) Pino et al. (2003). 
(India) and schuppenannone (Germany) (Fenner, Betti, Mentz, \& Rates, 2006; Pino, 2010). The pulp may be eaten raw and tastes aromatic sweet, with a custard-like flavor, and it is used also to prepare juices, jellies and compotes. In Brazil the fruits are highly appreciated (Andrade, Zoghbi, Maia, Fabricius, \& Marx, 2001).

Andrade et al. (2001) investigated the chemical characterization of the fruit of A. squamosa L. occurring in the Amazon. The presence of the diterpenoid compound kaur-16-en-18-oic acid in a considerable amount $(0.25 \%$ of dry mass) was detected in the lipid fraction. The essential oil of the fruit pulp was obtained and its volatile constituents were identified by GC/MS. The major compounds were $\alpha$-pinene (25.3\%), sabinene (22.7\%) and limonene (10.1\%) (Fig. 5).

The species A. glabra L. is a small tree called araticum-do-brejo, araticum-caca, araticum-cortiça, araticum-da-praia, araticum-de-boi, araticum-da-água, araticum-do-mangue and araticum-panam, which grows in many places in the north and north-east of Brazil (Santos et al., 1998). The common names include pond apple, alligator apple, monkey apple, corkwood, bobwood (United States) and bagá (Cuba) (Pino, 2010). The fruit has an edible yellow pulp and they are cultivated in Brazil and Central America (Santos et al., 1998).

Santos et al. (1998) analyzed by GC/MS the volatile constituents of the fruits of pond apple (A. glabra L.) growing wild in North Brazil. The most abundant class of compounds found in the aromas was terpenoids, principally $\alpha$-pinene, limonene, $\alpha$-phellandrene and

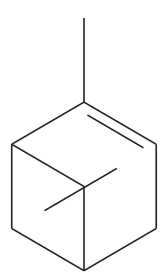

$\alpha$-pinene

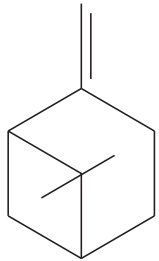

$\beta$-pinene

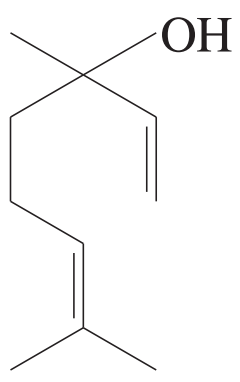

linalool

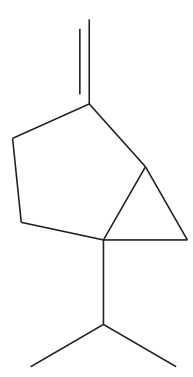

sabinene

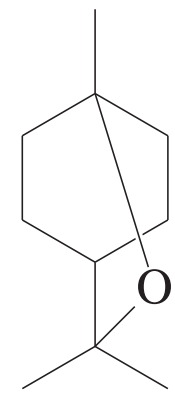

1,8-cineole

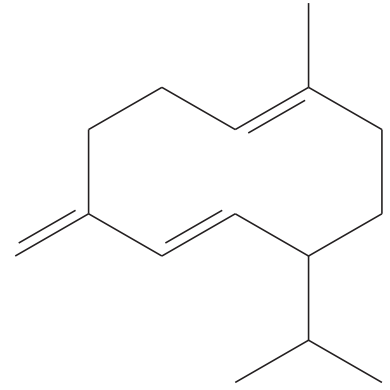

germacrene D

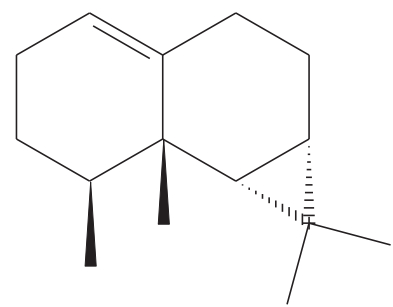

calarene
Fig. 5. Some of the main compounds present in the volatile fraction of the genus Annona.
(E)- $\beta$-ocimene. The concentrations of terpenoid compounds vary according to the different stages of ripening.

Wong and Khoo (1993) investigated the volatile compounds of three different Annona species from Malaysia. A total of fifty-one components were identified in the soursop volatiles, including eleven which have been previously reported in this fruit. Thirty-four volatile components were identified in the sweetsop and fifty-two in the bullock's heart. Most aroma components in the soursop were esters (57.2\%), while terpenoid constituents predominated in the sweetsop and bullock's heart ( $88.5 \%$ and $98.3 \%$ respectively).

Bullock's heart (A. reticulata L.) is very popular in Cuba, where it is commonly known as mamón. This fruit is also known as custard apple (United States), anona, anona colorada (México), corazón (Venezuela), anón pelón (Colombia), araticum-do-mato (Brazil) and others. This fruit has been introduced in diverse regions of the American tropics and Southeast Asia, without achieving a level of importance comparable to that of $A$. cherimolia or A. squamosa. Pulp is eaten fresh or made into sherbets and jams (Pino, 2010).

Volatile components of bullock's heart growing in Cuba were isolated by simultaneous steam distillation-solvent extraction analyzed by GC/MS. The major volatiles were $\beta$-pinene, $\alpha$-pinene, and germacrene D from the 49 identified constituents (Fig. 5). Furthermore, the volatile compounds were isolated from four cultivars of bullock's heart fruit from Cuba by simultaneous steam distillationsolvent extraction. In total, 180 volatile constituents were detected by HRGC and capillary GC/MS in the aroma extracts. The authors conclude that the presence of many terpene compounds is thought to contribute to the unique flavor of the bullock's heart fruit (Pino, Marbot, \& Fuentes, 2003).

Soursop (A. muricata) is a tropical fruit native to and common in tropical America and the West Indies, although it is grown in some other countries including Sri Lanka (MacLeod \& Pieris, 1981). The fruit contributed to the economic growth of several tropical countries in tropical America, Africa, Malaysia and Australia (Shashirekha, Baskaran, Rao, Vijayalakshmi, \& Rajarathnam, 2008) and can be utilized in the development of exotic processed products (Peters, Badre, \& Comissiong, 2001). This fruit is cherished for its unique and pleasant flavor, and the white pulp is usually used for manufacturing various kinds of products, i.e., juice blends, puree, syrups, jams and ice-cream (Franco \& Janzantti, 2005; Umme, Salmah, Jamilah, \& Asbi, 1999). Moreover, the soursop pulp has already been marketed in Europe, North America and Brazil (Gratão, Silveira, \& Telis-Romero, 2007).

Essential oil compounds of the A. muricata fresh fruit pulp from Cameroon were identified by Jirovetz, Buchbauer, and Ngassoum (1998), using a gas chromatographic/mass spectrometric (GC/FID and GC/MS) and olfactometric methods. More than 50 compounds were identified where esters of aliphatic acids are especially dominating, with methyl 2-hexenoate, ethyl 2-hexenoate, methyl 2-octenoate, and methyl 2-butenoate as main compounds. Additional mono- and sesquiterpenes such as $\alpha$-caryophyllene, 1,8-cineole, linalool, $R$ terpineol, linalyl propionate and calarene are highly concentrated in the essential oil of these fresh fruits (Fig. 5).

MacLeod and Pieris (1981) identified by GC/MS some aroma components in soursop (A. muricata) from Sri Lanka. Esters were the volatile compounds dominant in the samples, accounting for $80 \%$ of the total volatiles, and methyl hexanoate (31\%) and methyl hex2-enoate (27\%) were the two most abundant components of the fruit.

The volatile compounds in soursop (A. muricata L.) were obtained by a liquid-liquid continuous extraction procedure from the aqueous solution of blended soursop pulp and analyzed by GC and GC/MS. Twelve volatile compounds were identified, where five were identified tentatively from MS data only and, eight are being reported for the first time. $(Z)$-3-hexen-1-ol was the main volatile present in mature-green fruit, while methyl $(E)$-2-hexenoate, methyl $(E)$ 2-butenoate, methyl butanoate, and methyl hexanoate were the four main volatiles present in ripe fruit. Concentrations of these five 
<smiles>CCCCCC=O</smiles>

hexanal<smiles>CCC(C)C=O</smiles>

2-methyl butanal<smiles>CCOC(C)=O</smiles>

Ethyl acetate<smiles>CCCCOC(=O)c1ccccc1</smiles>

Butyl benzoate

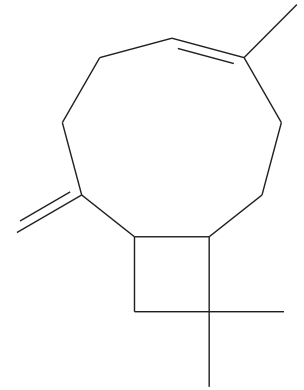

$\beta$-caryophyllene

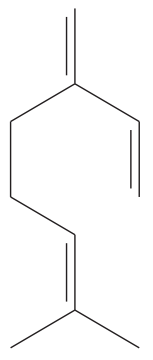

Myrcene

Fig. 6. Some of the main compounds present in the volatile fraction of Spondias species.

volatiles decreased and several other unidentified volatiles appeared when the fruit became overripe (Iwaoka, Zhang, Hamilton, Chia, \& Tang, 1993).

Recently, Cheong et al. (2010) evaluated the influence of some HS-SPME variables (sample concentration, salt concentration and sample amount), on the equilibrium headspace analysis of the main volatile flavor compounds released from soursop (A. muricata L.). A total of 35 volatile compounds, comprising 19 esters, six alcohols, three terpenes, two acids, two aromatics, two ketones and an aldehyde were identified. The results showed that the parameters evaluated were significant to provide a highest overall equilibrium headspace concentration for the target soursop volatile flavor compounds.

\section{The genus Spondias}

Spondias is a genus which belongs to the Anacardiaceae family and is extensively found in tropical areas of America, Africa and Asia (Adedeji, Hartman, Rosen, \& Ho, 1991; Augusto et al., 2000; Ceva-Antunes, Bizzo, Alves, \& Antunes, 2003; Ceva-Antunes, Bizzo, Silva, Carvalho, \& Antunes, 2006; Miller \& Schaal, 2005), comprising approximately 17 species. Almost all species have a fibrous endocarp and leaflets with an intramarginal vein. Neither the relationship of Spondias to closely related genera nor the relationships among the species are well understood (Miller \& Schaal, 2005).

This text focuses three of the most important species concerning the commercial and agricultural species: Spondias purpurea, Spondias mombin and Spondias tuberosa.

\subsection{S. purpurea}

S. purpurea, L., widely found in the northern part of South America (Augusto et al., 2000), Northeast of Brazil (Ceva-Antunes et al., 2006) and Central America, is native to the tropical dry forests of Mexico and Central America (Miller \& Schaal, 2005). There are at least 180 common names for the specie (Miller \& Schaal, 2005) among these are used siriguela (Augusto et al., 2000; Ceva-Antunes et al., 2006), jocote, ciruela mexicana, hog plum (Miller \& Schaal, 2005) and ovo (Koziol \& Macia, 1998). It is a small and reddish fruit that has a pleasant aroma and taste which is consumed in natura or as juice and jam (Augusto et al., 2000; Ceva-Antunes et al., 2006; Miller \& Schaal, 2005).
There are some studies reporting the volatile composition of this fruit. In an investigation of the pulp obtained from fresh fruit, samples were submitted to solid phase microextraction (SPME) using several types of SPME fibers combined with gas chromatography-quadrupole mass spectrometry (GC/qMS). DVB-CAR-PDMS showed to be the more efficient qualitative and semi-quantitative fiber in trapping these compounds. It identified 27 volatiles, especially ketones, alcohols, aldehydes, esters and terpene hydrocarbons in the headspace. Quantitatively, the preponderant were: hexanal (10.6\%), ethyl acetate (8.4\%), 3-hexen-1-ol (6.8\%), 2-hexen-1-ol (5\%), trans-2hexenal (5\%), and hexyl acetate (2\%) (Ceva-Antunes et al., 2006). Analogous compounds were found using the other fibers, even though, the proportions have been different: CW-DVB (19 compounds) 3-hexen-1-ol (6.6\%), hexanal (5.9\%) and trans-2-hexenal (3.1\%); CAR-PDMS (18 compounds) hexanal (18.5\%), ethyl acetate (11\%), 2-hexen-1-ol (8.8\%), and 3-hexen-1-ol (5.6\%), were the majority; PDMS (10 compounds) ethyl acetate (7.4\%), hexanal (6.8\%) and hexyl acetate (3.5\%) (Ceva-Antunes et al., 2006).

Similar types of compounds were found in other studies, although, in this case, industrialized pulps were used as samples. The analytes identified included several alcohols, esters, aldehydes, ketones and terpene hydrocarbons. The highest amounts extracted, evaluated from the sum of peak areas, as well the number of identified compounds (19), were achieved using a CAR-PDMS fiber (Augusto et al., 2000).

A third study agrees with the other since it showed the same groups of compounds as greater part of total. It was identified as major component 2-hexenal, whose peak area represented 38.99\%. Unfortunately the analysis could not distinguish between the trans and cis isomers, on the other hand, their odor and taste thresholds are analogous, with both showing an odor threshold of $0.01 \mathrm{ppm}$ and taste thresholds of 0.06 and $0.08 \mathrm{ppm}$, respectively. Although this compound is the most abundant, it is improbable that the aroma of S. purpurea derives primarily from one compound, but rather from the complex interaction of the various aromatics present. Beyond 2-hexenal other important compounds were hexanal $6.95 \%$ and hexadecanoic acid $18.51 \%$, which is virtually odorless (Koziol \& Macia, 1998).

\subsection{S. mombin}

The specie S. mombin, L. (or Spondias lutea L.), is an Amazonian plant commonly known as hog plum tree (Adedeji et al., 1991), yellow 
mombin (Narain, Galvão, \& Madruga, 2007), cajá, taperebá, cajámirim (Ceva-Antunes et al., 2003; Narain, Almeida, Galvão, Madruga, \& Brito, 2004) and jobo (Sagrero-Nieves \& Pooter, 1992). It is a yellow to orange small fruits with a pleasant acid taste and aroma. It is commercialized for the production of juices, ice cream and frozen pulp all over Brazil presenting some economic importance (Adedeji et al., 1991; Augusto et al., 2000; Ceva-Antunes et al., 2003).

The volatiles of S. mombin were previously studied by using of SDE in the 1980s, but at that time only eight volatiles were identified. Other studies analyzed fruits of $S$. mombin cultivated in two different places (which were identified by distinct names: cajá and taperebá) using two different techniques namely SPME and SDE. It identified 72 compounds spread in groups such as esters, aldehydes, carboxylic acids, alcohols, ketones, and terpene hydrocarbons and alcohols. When analyzed using SPME technique, 18 analytes were identified in taperebá and 47 in cajá. (E)-caryophyllene (18.7\%), ethyl butyrate (10.0\%), and ethyl hexanoate (7.0\%) were the most abundant volatiles in taperebá, whereas myrcene (41.1\%) and $\beta$-phellandrene (8.5\%) were the major compounds in cajá. In the taperebá SDE extract, 46 substances were identified, and $(Z)$ caryophyllene (13.2\%) and limonene (9.5\%) were predominant. From the 42 substances found in the SDE extract of cajá, the major components were myrcene $(38.0 \%)$ and p-cymene (6.2\%). The two fruits showed similar chromatograms upon the use of SDE and SPME. These methods made it possible to determine 30 identical components in both fruits by using SDE and 32 by using SPME (Ceva-Antunes et al., 2003).

In another work S. mombin was analyzed. Thirty four compounds were detected, being 13 aliphatic esters, and nine of them belonging to a series of the type $\mathrm{CH}_{3}\left(\mathrm{CH}_{2}\right)_{x} \mathrm{COO}\left(\mathrm{CH}_{2}\right)_{y} \mathrm{CH}_{3}$, where $x$ is an odd number and $y$ is an even number (e.g., ethyl acetate: $x=0, y=1$; ethyl butyrate: $x=2, y=1$; butyl acetate: $x=0, y=3$, etc.). Ethyl butyrate, 1 -butanol, ethyl caproate and $\alpha$-pinene peaks were the most intense in the CAR-PDMS while in the PDMS there are significant peaks of the terpenes $\alpha$-pinene, limonene, $\gamma$-terpinene, ocimene, fenchyl alcohol, copaene and caryophyllene (Augusto et al., 2000).

The volatiles in the pulp of these fruits were captured by dynamic headspace technique and were analyzed in a system of high-resolution gas chromatography and mass spectrometry. Thirty-one compounds were identified. The main classes of volatiles were esters, alcohols, aldehydes and ketones. The major components were butyl benzoate (14.8\%), citronel acetate (10.8\%), 2-methyl-1-propanol (10.3\%) and pentanal (8.27\%) (Narain et al., 2004). In another work using the same technique, the molecules found were different: ethyl butyrate (14.4\%), ethyl hexanoate (8.8\%), and hexyl butanoate (7.9\%), except ethyl acetate (14.4\%), which was a common molecule, but in very low concentration (0.51\%) (Sagrero-Nieves \& Pooter, 1992). It is important to mention that the localization of the cultures and the strain was different.

\subsection{S. tuberosa/Spondias cytherea}

Although its origin is unknown, cajá-umbu is considered a natural hybrid between cajá (S. mombin L.) and umbu (S. tuberosa Arruda Camara) fruits. It is a small round yellow fruit with refreshing aroma and sour flavor (Franco \& Shibamoto, 2000). It possesses some xerophytic characters and is widely spread in some northeastern Brazilian states (Franco \& Shibamoto, 2000; Narain et al., 2007; Silva, Figueiredo, Queiroz, \& Galdino, 2005). Although the production is

Table 6

The main compounds found in fruits of genus Spondias using different analytical methods. Some of their structures are found in Figs. 1, 2, 5 and 6.

\begin{tabular}{|c|c|c|c|c|}
\hline Spondias specie & Analytical method & Compound & Flavor & Ref. $^{\text {a }}$ \\
\hline \multirow[t]{2}{*}{ S. purpurea } & $\begin{array}{l}\text { SPME }(\text { DVB-CAR-PDMS } \\
(\text { I) }),(C W-D V B \\
(\text { CAR-PDMS } \\
(\text { III) }) \text { e }\left(\text { PDMS }^{(I V)}\right) \text { followed by GC/MS }\end{array}$ & $\begin{array}{l}\text { hexanal }^{(\mathrm{I})(\mathrm{II})(\mathrm{III})(\mathrm{IV})} \\
\text { ethyl acetate }^{(\mathrm{I})(\mathrm{III})(\mathrm{IV})} \\
\text { 3-hexen-1-ol }^{(\mathrm{I})(\mathrm{II})} \\
\text { trans-2-hexenal }^{(\mathrm{II})} \\
\text { 2-hexen-1-ol }^{(\mathrm{III})} \\
\text { hexyl acetate }^{(\mathrm{IV})}\end{array}$ & $\begin{array}{l}\text { Grass, tallow, fat } \\
\text { Pineapple, fruit } \\
\text { Grass (Z); moss, fresh (E) } \\
\text { Green, leaf } \\
\text { Leaf, green, wine, fruit } \\
\text { Fruit, herb }\end{array}$ & 1) \\
\hline & SDE-GC/MS & $\begin{array}{l}\text { 2-hexenal } \\
\text { hexanal } \\
\text { hexadecanoic acid }\end{array}$ & $\begin{array}{l}\text { Apple, green } \\
\text { Grass, tallow, fat } \\
\text { Virtually odorless }\end{array}$ & 2) \\
\hline \multirow[t]{4}{*}{ S. mombin } & $\begin{array}{l}\text { SPME (CAR-PDMS and PDMS } \\
\text { followed by GC/MS }\end{array}$ & $\begin{array}{l}\text { caryophyllene }^{(\mathrm{I})(\mathrm{II})} \\
\text { ethyl butyrate }^{(\mathrm{I})} \\
\text { ethyl hexanoate }^{(\mathrm{I})} \\
\text { myrcene }^{(\mathrm{I})(\mathrm{II})} \\
\beta \text {-phellandrene } \\
\text { limonene }^{(\mathrm{II})} \\
\text { p-cymene }^{(\mathrm{II})}\end{array}$ & $\begin{array}{l}\text { Wood, spice } \\
\text { Apple } \\
\text { Apple peel, fruit } \\
\text { Balsamic, must, spice } \\
\text { Mint, turpentine } \\
\text { Lemon, orange } \\
\text { Solvente, gasoline, citrus }\end{array}$ & 3) \\
\hline & SPME (CAR-PDMS ${ }^{(\mathrm{I})}$ and PDMS $\left.{ }^{(\mathrm{II})}\right)$ & $\begin{array}{l}\alpha \text {-pinene }{ }^{(\mathrm{I})(\mathrm{II})} \\
\text { ethyl butyrate }^{(\mathrm{I})} \\
1 \text {-butanol } \\
\text { ethyl caproate }^{(\mathrm{I})} \\
\text { limonene }^{(\mathrm{II})} \\
\gamma \text {-terpinene } \\
\text { ocimene }^{(\mathrm{II})}\end{array}$ & $\begin{array}{l}\text { Pine, turpentine } \\
\text { Apple } \\
\text { Medicine, fruit, wine } \\
\text { Apple peel, fruit } \\
\text { Lemon, orange } \\
\text { Gasoline, turpentine } \\
\text { Herb }\end{array}$ & 4) \\
\hline & Purge and trap followed by GC/MS & $\begin{array}{l}\text { butyl benzoate } \\
\text { citronel acetate } \\
\text { 2-methyl-1-propanol } \\
\text { pentanal }\end{array}$ & $\begin{array}{l}\text { Balsamic } \\
\text { Fruit, sweet, rose } \\
\text { Alcohol, pungent } \\
\text { Almond, malt pungent }\end{array}$ & 5) \\
\hline & Purge and trap followed by GC/MS & $\begin{array}{l}\text { ethyl acetate } \\
\text { ethyl hexanoate } \\
\text { hexyl butyrate }\end{array}$ & $\begin{array}{l}\text { Pineapple, fruit } \\
\text { Apple peel, fruit } \\
\text { Apple peel }\end{array}$ & 6) \\
\hline \multirow[t]{2}{*}{ S. tuberosa } & Purge and trap followed by GC/MS & $\begin{array}{l}\text { } \text {-caryophyllene } \\
\text { 2-methyl butanal } \\
\text { 3-hexanol } \\
\text { ethyl butyrate }\end{array}$ & $\begin{array}{l}\text { Wood, spice } \\
\text { Pungent, fresh fruit } \\
\text { Resin, flower, green } \\
\text { Cognac, fruit, sweet }\end{array}$ & 7) \\
\hline & SDE followed by GC/MS & $\begin{array}{l}\text { limonene } \\
\text { 1-heptanol } \\
\text { 2-pentanol } \\
\text { 3-hexanol }\end{array}$ & $\begin{array}{l}\text { Lemon, orange } \\
\text { Herb } \\
\text { Green } \\
\text { Resin, flower, green }\end{array}$ & 8) \\
\hline
\end{tabular}

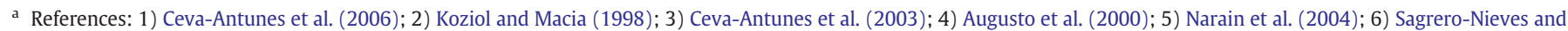
Pooter (1992); 7) Narain et al. (2007); 8) Galvão et al. (2010). 
small scale (Narain et al., 2007), its cultivation is spread and presents great economical potentials, especially in the market of exotic fruits for the production of juices, ice cream and frozen pulp (Franco \& Shibamoto, 2000; Narain et al., 2007; Silva et al., 2005). Furthermore, the use of $S$. cytherea, characterizing specie of the caja-umbu fruit, is a misnomer as it represents the fruit ambarella (Leon \& Shaw, 1990).

There is few data on post-harvest aspects concerning physical, physico-chemical and chemical characteristics of this fruit at different stages of maturation. In addition, the study of the volatile compounds is very scarce. In a precursory work, Narain et al. (2007) have identified the volatile compounds present in the pulp of fruits harvested at two different stages of maturation (half-ripe and ripe) using the technique of purge and trap to capture these compounds. In half-ripe fruit, 67 volatiles were found. The main components were identified as $\beta$-caryophyllene (22.2\%), 2-methyl butanal (19.3\%), 2-hexanol (18.6\%), ethyl butyrate (7.6\%) and $\alpha$-caryophyllene (3.9\%). In the ripe fruit, 70 compounds were identified. Quantitatively, the prominent were 2-methyl butanal (28.4\%), 2-hexanol (15.0\%), $\beta$-caryophyllene (14.1\%), ethyl butyrate (6.1\%) and $\alpha$-caryophyllene (2.4\%). The authors noticed that there is a notable quantitative distinction in prominent analytes such as $\beta$-caryophyllene and 2 -hexanol which were quantitatively higher in half-ripe fruits while 2-methyl butanal, known to present pungent fresh fruit aroma, increased with maturation.

Another work of the same research group has determined the volatile constituents in half ripe and ripe stages of $S$. tuberosa fruit. The extraction of volatiles was carried out through SDE and analyzed in a GC/MS. A total of 148 compounds were detected in half ripe and 159 in ripe fruit pulp. The principal compounds identified in the ripe fruit pulp were limonene, 1-heptanol, 2-pentanol, 3-hexanol, 1-nonanol, 2-octanol; 2-nonanol, 2,2-dimethyl 4-octenal, 3-methyl ethyl 2butanoate, butyl benzoate, 3-allyl cyclohexene, 2-acetyl furan, 1penten-3-one, 3-hexanone, 5-methyl furfural, 2-hexyl furan, $\beta$ caryophyllene and methyl-pyrazine (Galvão, Narain, Madruga, \& Santos, 2010), which is very similar to the volatiles found in cajáumbu as well as in all fruits of the Spondias genus.

A summary of all compounds detected in the species of Spondias described is shown in Table 6.

\section{Concluding remarks}

The fruits described in this text have been traditionally appreciated in tropical regions. However, their diffuse production and their crop restricted to some scattered localities have resulted in low economic importance. The increasing interest for eccentric tastes is now changing this scenario. The growing market for exotic fruits and juices forces the scientific community to characterize these fruits. In this context, the composition of the volatile fraction of fruits is essential for several applications in food industry. This paper reviewed the most recent advances for the characterization and analytical techniques used to characterize the volatile fraction of selected exotic fruits with growing interest in the Brazilian market: Brazilian cherry (E. uniflora), acerola (M. glabra L., M. punicifolia L., M. emarginata DC.), jackfruit (A. heterophyllus), starfruit (Averrhoa carambola) and fruits from the genera Annona (cherimoya, soursop, sugar apple etc.) and Spondias (S. purpurea, S. mombin and S. tuberosa). The descriptions of the main flavor compounds as well as some of the compounds that can contribute for the aroma of these fruits were commented.

\section{References}

Adedeji, J., Hartman, T. G., Rosen, R. T., \& Ho, C. T. (1991). Free and glycosidically bound aroma compounds in Hog Plum (Spondias mombin L.). Journal of Agricultural and Food Chemistry, 39, 1494-1497.

Ajayi, I. A. (2008). Comparative study of the chemical composition and mineral element content of Artocarpus heterophyllus and Treculia africana seeds and seed oils. Bioresource Technology, 99, 5125-5129.
Amoo, I. A., Emenike, A. E., \& Akpambang, V. O. E. (2008). Composition evaluation of Annona cherimoya (Custard Apple) fruit. Trends in Applied Sciences Research, 3, 216-220.

Amorim, A. C. L., Lima, C. K. F., Hovell, A. M. C., Miranda, A. L. P., \& Rezende, C. M. (2009) Antinociceptive and hypothermic evaluation of the leaf essential oil and isolated terpenoids from Eugenia uniflora L. (Brazilian Pitanga). Phytomedicine, 16, 923-928.

Andrade, E. H. A., Zoghbi, M. G. B., Maia, J. H. G. S., Fabricius, H., \& Marx, F. (2001). Chemical characterization of the fruit of Annona squamosa L. occurring in the Amazon. Journal of Food Composition and Analysis, 14, 227-232.

Arai, I., Amagaya, S., Komatsu, Y., Okada, M., Hayashi, T., Kasai, M., et al. (1999). Improving effects of the extract from Eugenia uniflora on hyperglycemia and hypertriglyceridemia in mice. Journal of Ethnopharmacology, 68, 307-314.

Araújo, P. S. R., \& Minami, K. (1994). Acerola.Campinas: Fundação Cargill 81 pp.

Asquieri, E. R., Rabelo, A. M. S., \& Silva, A. G. M. (2008). Fermentado de jaca: estudo das características físico-químicas e sensoriais. Ciência e Tecnologia dos Alimentos, 28, $881-887$.

Assis, S. A., Fernandes, P. F., Martins, A. B. G., \& Oliveira, O. M. M. F. (2008). Acerola: Importance culture conditions, production and biochemical aspects. Fruits, 63, 93-101.

Augusto, F., Valente, A. L. P., Tada, E. S., \& Rivellino, R. S. (2000). Screening of Brazilian fruit aromas using solid-phase microextraction-gas chromatography-mass spectrometry. Journal of Chromatography A, 873, 117-127.

Auricchio, M. T., \& Bacchi, E. M. (2003). Folhas de Eugenia uniflora L. (pitanga): Revisão. Revista do Instituto Adolfo Lutz, 62, 55-61.

Bagetti, M., Facco, E. M. P., Rodrigues, D. B., Vizzotto, M., \& Emanuelli, T. (2009). Antioxidant capacity and composition of pitanga seeds. Ciência Rural, 39, 2504-2510.

Boulanger, R., \& Crouzet, J. (2001). Identification of the aroma components of acerola (Malphigia glabra L.): Free and bound flavor compounds. Food Chemistry, 74, 209-216.

Cavalcante, P. B. (1991). Frutas comestíveis da Amazônia.Belém: Editora CEJUP 269 pp.

Ceva-Antunes, P. M. N., Bizzo, H. R. Alves, S. M. \& Antunes, O. A. C. (2003). Analysis of volatile compounds of Taperebá (Spondias mombin L.) and Cajá (Spondias mombin L.) by simultaneous distillation and extraction (SDE) and solid phase microextraction (SPME). Journal of Agricultural and Food Chemistry, 51, 1387-1392.

Ceva-Antunes, P. M. N., Bizzo, H. R., Silva, A. S., Carvalho, C. P. S., \& Antunes, O. A. C (2006). Analysis of volatile composition of siriguela (Spondias purpurea L.) by solid phase microextraction (SPME). LWT, 39, 436-442.

Cheong, K. W., Tan, C. P., Mirhosseini, H., Hamid, N. S. A., Osman, A., \& Basri, M. (2010) Equilibrium headspace analysis of volatile flavor compounds extracted from soursop (Annona muricata) using solid-phase microextraction. Food Research International, 43, 1267-1276.

Chikhalikar, N. V., Sahoo, A. K., Singhal, R. S., \& Kulkarni, P. R. (2000). Studies on frozen pourable custard apple (Annona squamosa L.) pulp using cryoprotectants. Journal of the Science of Food and Agriculture, 80, 1339-1342.

Consolini, A. E., Baldini, O. A. N., \& Amat, A. G. (1999). Pharmacological basis for the empirical use of Eugenia uniflora L. (Myrtaceae) as antihypertensive. Journal of Ethnopharmacology, 66, 33-39.

Consolini, A. E., \& Sarubbio, M. G. (2002). Pharmacological effects of Eugenia uniflora (Myrtaceae) aqueous crude extract on rat's heart. Journal of Ethnopharmacology, 81 $57-63$.

Crane, J. H. (1994). The carambola. Fact Sheet HS-12, University of Florida: IFAS Extension (6 pp.).

Faria, A. F., Rosso, V. V., \& Mercadante, A. Z. (2009). Carotenoid composition of jackfruit (Artocarpus heterophyllus), determined by HPLC-PDA-MS/MS. Plant Foods for Human Nutrition, 64, 108-115.

Fenner, R., Betti, A. H., Mentz, L. A., \& Rates, S. M. K. (2006). Plantas utilizadas na medicina popular brasileira com potencial atividade antifúngica. Brazilian Journal of Pharmaceutical Sciences, 42, 369-394.

Ferreira, L., Perestrelo, R., \& Câmara, J. S. (2009). Comparative analysis of the volatile fraction from Annona cherimola Mill. cultivars by solid-phase microextraction and gas chromatography-quadrupole mass spectrometry detection. Talanta, 77, 1087-1096.

Filho, G. L., De Rosso, V. V., Meireles, M. A. A., Rosa, P. T. V., Oliveira, A. L., Mercadante, A. Z. et al. (2008). Supercritical $\mathrm{CO}_{2}$ extraction of carotenoids from pitanga fruits (Eugenia uniflora L.). The Journal of Supercritical Fluids, 46, 33-39.

Fleischmann, P., Watanabe, N., \& Winterhalter, P. (2003). Enzymatic carotenoid cleavage in star fruit (Averrhoa carambola L.). Phytochemistry, 63, 131-137.

Fraga, S.R.G. (2005). Investigação dos voláteis e precursores de voláteis glicosilados da Jaca (Artocarpus heterophyllus Lam.) e do Muruci (Byrsonima crassifolia Lam. Rich). Doctoral thesis. Federal University of Rio de Janeiro, Institute of Chemistry.

Franco, M. R. B., \& Janzantti, N. S. (2005). Aroma of minor tropical fruits. Flavour and Fragrance Journal, 20, 358-37.

Franco, M. R. B., \& Shibamoto, T. (2000). Volatile composition of some Brazilian fruits: Umbu-caja (Spondias citherea), Camu-camu (Myrciaria dubia), Araça-boi (Eugenia stipitata), and Cupuaçu (Theobroma grandiflorum). Journal of Agricultural and Food Chemistry, 48, 1263-1265.

Franzão, A. A., \& Melo, B. (2010). Cultura da pitangueira. Available at. www.fruticultura. iciag.ufu.br/pitangueira.html Accessed in July, 2010.

Galvão, M. S., Narain, N., Madruga, M. S., \& Santos, M. S. P. (2010). Volatile compounds in Umbu (Spondias tuberosa Arruda Câmara) fruits during maturation. Acta Horticulturae, 864, 509-517.

Gomez, P., Reynes, M., Dornier, M., \& Hebert, J. P. (1999). The West Indian cherry: A valuable and natural source of vitamin C. Fruits, 54, 247-260.

Gratão, A. C. A., Silveira, V., Jr., \& Telis-Romero, J. (2007). Laminar flow of soursop juice through concentric annuli: Friction factors and rheology. Journal of Food Engineering $78,1343-1354$

Idstein, H., Herres, W., \& Schreier, P. (1984). High-resolution gas chromatography-mass spectrometry and -Fourier transform infrared analysis of cherimoya (Annona cherimolia, Mill.) volatiles. Journal of Agricultural Food Chemistry, 32, 383-389. 
Iwaoka, W. T.,Zhang, X., Hamilton, R. A., Chia, C. L., \& Tang, C. S. (1993). Identifying volatiles in soursop and comparing their changing profiles during ripening. Hort Science, 28, $817-819$.

Jirovetz, L., Buchbauer, G., \& Ngassoum, M. B. (1998). Essential oil compounds of the Annona muricata fresh fruit pulp from Cameroon. Journal of Agricultural and Food Chemistry, 46, 3719-3720.

Johnson, P. D. (2003). Acerola (Malpighia glabra L., Malpighia punicifolia L., Malpighia emarginata DC.): Agriculture, production and nutrition. World Review of Nutrition and Dietetics, 91, 67-75.

Kanazawa, A., Patin, A., \& Greene, A. E. (2000). Efficient, highly enantioselective synthesis of selina-1, 3, 7(11)-trien-8-one, a major component of the essential oil of Eugenia uniflora. Journal of Natural Products, 63, 1292-1294.

Koziol, M. J., \& Macia, M. J. (1998). Chemical composition, nutritional evaluation, and economic prospects of Spondias purpurea (Anacardiaceae). Economic Botany, 52, $373-380$.

Leon, J., \& Shaw, P. E. (1990). Spondias: The red mombin and related fruits. In S. Nagy, P. E. Shaw, \& W. F. Wardowski (Eds.), Fruits of tropical and subtropical origin (pp. 116-126). Lake Alfred: Florida Science Source.

Leung, A. Y., \& Foster, S. (1996). Acerola. Encyclopedia of common natural ingredients used in food, drugs, and cosmetics (pp. 6-7). New York: Wiley.

Lima, V. L. A. G., Melo, E. A., \& Lima, D. E. S. (2002). Fenólicos e carotenóides totais em pitanga. Scientia Agricola, 59, 447-450.

Maciel, M. I. S., Melo, E. D. A., Lima, V. L. A., da Silva, M. R. F., \& da Silva, I. P. (1999) Processing and storage of acerola (Malpighia sp.) fruit and its products. Journal of Food Science and Technology, 36, 142-146.

MacLeod, G., \& Ames, J. M. (1990). Volatile components of starfruit. Phytochemistry, 29, $165-172$

MacLeod, A. J., \& Pieris, N. M. (1981). Volatile flavor components of soursop (Annona muricata). Journal of Agricultural and Food Chemistry, 29, 488-490.

Maia, J. G. S., Andrade, E. H. A., \& Zoghbi, M. D. B. (2004). Aroma volatiles from two fruit varieties of jackfruit (Artocarpus heterophyllus Lam.). Food Chemistry, 85 195-197.

Malaman, F. S., Moraes, L. A. B., West, C., Ferreira, N. J., \& Oliveira, A. L. (2010). Supercritical fluid extracts from the Brazilian cherry (Eugenia uniflora L.) Relationship between the extracted compounds and the characteristic flavor intensity of the fruit. Food Chemistry, 124, 85-92.

Marin, R., Apel, M. A., Limberger, R. P., Raseira, M. C. B., Pereira, J. F. M., Zuanazzi, J. A. S., et al (2008). Volatile components and antioxidant activity from some Myrtaceous fruit cultivated in Southern Brazil. Latin American Journal of Pharmacy, 27, 172-177.

Maróstica, M. R., Jr., \& Pastore, G. M. (2007). Tropical fruit flavor (Chapter 8). In R. C. Berger (Ed.), Flavours and fragrances: Chemistry, bioprocessing and sustainability (pp. 189-201). Berlin: Springer

Matsumura, T., Kasai, M., Hayashi, T., Arisawa, M., Momose, Y., Arai, I., et al. (2000). $\alpha$ Glucosidase inhibitors from Paraguayan natural medicine, Ñangapiry, the leaves of Eugenia uniflora. Pharmaceutical Biology, 38, 302-307.

Melo, R. M., Corrêa, V. F. S., Amorim, A. C. L., Miranda, A. L. P., \& Rezende, C. M. (2007) Identification of impact aroma compounds in Eugenia uniflora L. (Brazilian Pitanga) leaf essential oil. Journal of Brazilian Chemical Society, 18, 179-183.

Mezadri, T., Fernández-Pachón, M. S., Villaño, D., García-Parrilla, M. C., \& Troncoso, A. M. (2006). El fruto de la acerola: composición y posibles usos alimentícios. Archivos Latinoamericanos Nutrición, 56, 101-109.

Miller, A., \& Schaal, B. (2005). Domestication of a Mesoamerican cultivated fruit tree Spondias purpurea. PNAS, 102, 12801-12806.

Moreno, P. R. H., Lima, M. E. L., Sobral, M., Cláudia, M., Young, M., Cordeiro, I., et al (2007). Essential oil composition of fruit colour varieties of Eugenia brasiliensis Lam. Scientia Agricola, 64, 428-432.

Morton, J. (1987). Carambola. Fruits of warm climates (pp. 125-128). Available at: http:// www.hort.purdue.edu/newcrop/morton/carambola.html accessed September 3rd 2010.

Narain, N., Almeida, J. N., Galvão, M. S., Madruga, M. S., \& Brito, E. S. (2004). Compostos voláteis dos frutos de maracujá (Passiflora edulis forma Flavicarpa) e de cajá (Spondias mombin L.) obtidos pela técnica de headspace dinâmico. Ciência e Tecnologia Alimentos, 24, 212-216.

Narain, N., Galvão, M. S., \& Madruga, M. S. (2007). Volatile compounds captured through purge and trap technique in caja-umbu (Spondias sp.) fruits during maturation. Food Chemistry, 102, 726-731.

Narasimham, P. (1990). Breadfruit and jackfruit. In S. Nagy, P. E. Shaw, \& W. F. Wardowsk (Eds.), Fruits of tropical and subtropical origin (pp. 193-259). : Florida Science Source.

Netto, A. G., Ardito, E. F. G., Garcia, E. E. C., Bleinroth, E. W., Freire, F. C. O., Menezes, J. B. et al. (1996). Acerola para exportação: procedimentos de colheita e pós-colheita. Brasília, Brazil: EMBRAPA - SPI.

Neves, L. C., Bender, R. J., Rombaldi, C. V., \& Vieites, R. L. (2004). Qualidade de carambolas azedas cv. 'Golden Star' tratadas com $\mathrm{CaCl}_{2}$ por imersão e armazenadas sob refrigeração. Revista Brasileira de Fruticultura, 26, 32-35.

Ogunwande, I. A., Olawore, N. O., Ekundayo, O., Walker, T. M., Schmidt, J. M., \& Setzer, W. N. (2005). Studies on the essential oils composition, antibacterial and cytotoxicity of Eugenia uniflora L. The International Journal of Aromatherapy, 15, 147-152.

Olias, J. M., Sanz, C., Rios, J. J., \& Perez, A. G. (1995). Substrates specificity of alcoho acyltransferase from strawberry and banana fruits. Fruit flavors. ACS Symposium Series. (pp. 135-141)

Oliveira, L.F. (2009). Efeito dos parâmetros do processo de desidratação de jaca (Artocarpus heterophyllus, Lam.) sobre as propriedades químicas, físico-químicas e aceitação sensorial. Doctoral thesis. Rural Federal University of Rio de Janeiro, Food Technology.

Oliveira, M. D. L., Andrade, C. A. S., Santos-Magalhães, N. S, Coelho, L. C. B. B., Teixeira, J. A Carneiro-da-Cunha, M. G., et al. (2008). Purification of a lectin from Eugenia uniflora L. seeds and its potential antibacterial activity. Letters in Applied Microbiology, 46, $371-376$.

Oliveira, A. L., Kamimura, E. S., \& Rabi, J. A. (2009). Response surface analysis of extract yield and flavor intensity of Brazilian cherry (Eugenia uniflora L.) obtained by supercritical carbon dioxide extraction. Innovative Food Science \& Emerging Technologies, 10, 189-194.

Oliveira, A. L., Lopes, R. B., Cabral, F. A., \& Eberlin, M. N. (2006). Volatile compounds from pitanga fruit (Eugenia uniflora L.). Food Chemistry, 99, 1-5.

Ong, B. T., Nazimah, S. A. H., Osman, A., Quek, S. Y., Voon, Y. Y., Hashim, D. M., et al. (2006). Chemical and flavor changes in jackfruit (Artocarpus heterophyllus Lam.) cultivar J3 during ripening. Postharvest Biology and Technology, 40, 279-286.

Ong B. T. Nazimah, S. A. H. Tan, C. P., Mirhosseini, H., Osman, A., Mat Hashim, D., et al. (2008). Analysis of volatile compounds in five jackfruit (Artocarpus heterophyllus L.) cultivars using solid-phase microextraction (SPME) and gas chromatographytime-of-flight mass spectrometry (GC-TOFMS). Journal of Food Composition and Analysis, 21, 416-422.

Peters, M., Badre, N., \& Comissiong, E. (2001). Processing and quality evaluation of soursop (Annona muricata L.) nectar. Journal of Food Quality, 24, 361-374.

Pino, J. (2010). Annona fruits (chapter 14). Handbook of Fruit and Vegetable Flavors (pp. 231-247). New Jersey: Hoboken.

Pino, J. A., Bello, A., Urquiola, A., Aguero, J., \& Marbot, R. (2003). Fruit volatiles of Cayena cherry (Eugenia uniflora L.) from Cuba. Journal of Essential Oil Research, 15, 70-71.

Pino, J. A., \& Marbot, R. (2001). Volatile flavor constituents of acerola (Malpighia emarginata DC.) fruit. Journal of Agricultural and Food Chemistry, 49, 5880-5882.

Pino, J. A., Marbot, R., \& Fuentes, V. (2003). Characterization of volatiles in Bullock's Heart (Annona reticulata L.) fruit cultivars from Cuba. Journal of Agricultural and Food Chemistry, 51, 3836-3839.

Pino, J., Marbot, R., Rosado, A., \& Bello, A. (2004). Volatile components of Averrhoa bilimbi L. fruit grown in Cuba. Journal of Essential Oil Research, 16, 241-242.

Pua, C. K., Hamid, N. S. A., Rusul, G., \& Rahman, R. A. (2007). Production of drum-dried jackfruit (Artocarpus heterophyllus) powder with different concentration of soy lecithin and gum arabic. Journal of Food Engineering, 78, 630-636.

Rahman, A. K. M. M., Huq, E., Mian, A. J., \& Chesson, A. (1995). Microscopic and chemical changes occurring during the ripening of two forms of jackfruit (Artocarpus heterophyllus L.). Food Chemistry, 52, 405-410.

Rahman, M. A., Nahar, N., Mian, A. J., \& Mosihuzzaman, M. (1999). Variation of carbohydrate composition of two forms of fruit from jack tree (Artocarpus heterophyllus L.) with maturity and climatic conditions. Food Chemistry, 65, 91-97.

Rasmussen, P. (1983). Identification of volatile components of jackfruit by gas chromatography/mass spectrometry by two different columns. Analytical Chemistry, $55,1331-1335$

Rücker, G., Silva, G. A. A. B. E., Bauer, L., \& Schikarski, M. (1977). New constituents of Stenocalyx michelii. Planta Medica, 31, 322-327.

Sagrero-Nieves, L., \& Pooter, H. L. D. E. (1992). Volatiles of the Jobo fruit. Journal of Essential Oil Research, 4, 535-537.

Santos, A. S., Andrade, E. H. A., Zoghbil, M. G. B., \& Maia, J. G. S. (1998). Volatile constituents of fruits of Annona glabra L. from Brazil. Flavour and Fragance Journal, $13,148-150$

Schapoval, E. E. S., Silveira, S. M., Miranda, M. L., Alice, C. B., \& Henriques, A. T. (1994). Evaluation of some pharmacological activities of Eugenia uniflora L. Journal of Ethnopharmacology, 44, 137-142.

Schippa, C., George, G., \& Fellous, R. (1993). Constituants volatils de l'acérola. Parfums, Cosmétiques, Arômes, 113, 81-84.

Shashirekha, M. N., Baskaran, R., Rao, L. J., Vijayalakshmi, M. R., \& Rajarathnam, S. (2008). Influence of processing conditions on flavour compounds of custard apple (Annona squamosa L.). LWT. - Food Science and Technology, 41, 236-243.

Shu, C. -K. \& Lawrence, B. M. (1997). Reasons for the variation in composition of some commercial essential oils. Spices: Flavor chemistry and antioxidant properties. In S. J. Risch, \& C. -T. Ho (Eds.), Washington, DC: ACS Symposium Series. (pp. 138-159).

Silva, S. M. (2006). Pitanga. Revista Brasileira de Fruticultura, 28, 1-159.

Silva, R. N. G., Figueiredo, R. M. F., Queiroz, A. J. M., \& Galdino, P. O. (2005). Armazenamento de umbu-cajá em pó. Ciência Rural, 35, 1179-1184.

Spada, P. D. S., Souza, G. G. N., Bertolini, G. V., Henriques, J. A. P., \& Salvador, M. (2008). Antioxidant, mutagenic, and antimutagenic activity of frozen fruits. Journal of Medicinal Food, 11, 144-151.

Speirs, J., \& Brady, C. J. (1991). Modification of gene expression in ripening fruit. Australian Journal of Plant Physiology, 18, 519-532.

Swords, G., Swords, P. A., Bobbio, S., \& Hunter, G. L. K. (1978). A research note: Volatile constituents of jackfruit (Artocarpus heterophyllus). Journal of Food Science, 43, 639-640.

Umme, A., Salmah, Y., Jamilah, B., \& Asbi, B. A. (1999). Microbial and enzymatic changes in natural soursop puree during storage. Food Chemistry, 65, 315-322.

Vendramini, A. L., \& Trugo, L. C. (2000). Chemical composition of acerola fruit (Malpighia punicifolia L.) at three stages of maturity. Food Chemistry, 71, 195-198.

Vizzotto, M. (2008). Pitanga: uma fruta especial. EMBRAPA, April 24th. Available at. http://www.embrapa.gov.br/embrapa/imprensa/artigos/2008/pitanga-uma-frutaespecial-2 Accessed in July 2010.

Wilson, C. W., Shaw, P. E., Knight, R. J., Nagy, S., \& Klim, M. (1985). Volatile constituents of carambola. Journal of Agricultural and Food Chemistry, 33, 199-201.

Winterhalter, P., \& Schreier, P. (1995). The generation of norisoprenoid volatiles in starfruit (Averrhoa carambola L.): A review. Food Reviews International, 11, 237-254.

Wong, K. C., \& Khoo, K. H. (1993). Volatile components of Malaysian Annona fruits. Flavor and Fragrances Journal, 8, 5-10.

Wong, K. C., Lim, C. L., \& Wong, L. L. (1992). Volatile flavor constituents of Chempedak (Artocarpus polyphema Pers.) fruit and Jackfruit (Artocarpus heterophyllus Lam.) from Malaysia. Flavor and Fragrance Journal, 9, 319-324. 